\title{
Planktonic Foraminiferal Biostratigraphy and Correlation Across the Cretaceous-Paleogene Transition at the Tethyan and the Atlantic Realms
}

\author{
Njoud Gallala \\ Département de Civilisation, Institut Supérieur de Théologie de Tunis, Université Ez-Zitouna, 21 Rue Sidi Aboulkacem Jelizi, \\ Place du Leader, 1008 Tunis, Tunisia \\ Correspondence should be addressed to Njoud Gallala; gnoujoud@gmail.com
}

Received 29 October 2012; Revised 13 January 2013; Accepted 26 January 2013

Academic Editor: Marcelle BouDagher-Fadel

Copyright @ 2013 Njoud Gallala. This is an open access article distributed under the Creative Commons Attribution License, which permits unrestricted use, distribution, and reproduction in any medium, provided the original work is properly cited.

\begin{abstract}
Based on high-resolution planktonic foraminiferal biostratigraphical analysis at El Kef stratotype section (GSSP for the K/Pg boundary), Ellès section in Tunisia, and Agost and Caravaca sections in Spain (Tethyan realm), we attempt to compare biozones and subzones with those of the Bidart section (SW France) (Atlantic realm). The Abathomphalus mayaroensis zone of the upper Maastrichtian corresponds to the taxon range interval of the nominate species. We have identified the Plummerita hantkeninoides subzone. This species is present and associated with Pseudoguembelina hariaensis at the Tethyan realm. However, this species is absent at the middle latitude of the Atlantic realm (Bidart section, SW France). The Pseudoguembelina hariaensis species had larger paleogeographic spread, as it was present in both the Tethys and the Atlantic paleoceans. It is more relevant to be considered as the biomarker of a nominate uppermost Maastrichtian subzone instead of Plummerita hantkeninoides. The Danian stage is characterized by the Gt. cretacea zone, Pv. eugubina zone, and the Parasubbotina pseudobulloides zone. The deposition thickness of the zones and subzones at El Kef stratotype section and Ellès section is more expanded than at Agost and Caravaca sections (Spain) and Bidart section (France). They would be controlled by the sedimentary basin morphology.
\end{abstract}

\section{Introduction}

At the K/Pg boundary, with most of the Heterohelicids, the Globotruncanids suffered mass extinctions. These extinctions affecting many other biological groups of vertebrates and invertebrates induced a major crisis considered as the most severe and catastrophic biological event in the history of our planet. This crisis documented in many research on the foraminifers groups ([4-6], among others) became more accurate until the specialists began to use the high resolution biostratigraphical analyses ([7-16], among others).

The extinction model of planktic foraminifers groups, at the $\mathrm{K} / \mathrm{Pg}$ boundary, is very controversial. Some authors consider that the lower Danian assemblages include reworked specimens of Maastrichtian taxa [17-19], whereas others have suggested that at least a substantial part of the latest Maastrichtian species survived into the earliest Danian $[20,21]$.
Deep-water benthic foraminifers were less influenced by the $\mathrm{K} / \mathrm{Pg}$ boundary event, but their diversity and abundance decreased temporarily $[15,22,23]$.

After these $\mathrm{K} / \mathrm{Pg}$ boundary mass extinctions, small and new planktic foraminiferal species began to appear following an "explosive" adaptive radiation pattern. Consistent debates on the upper Maastrichtian-lower Danian interval based on planktic foraminiferal zonations and biochronology for the middle and lower latitudes are documented ([7, 8, 10, 12-16, 24-26], among others).

In general, the authors are disagreeing about the extinct species at the upper Maastrichtian than about the appeared species at the lower Danian. The estimate evolution and diversification of planktic foraminifers before and after the $\mathrm{K} / \mathrm{Pg}$ mass extinctions depend firstly on the resolution sampling across the K-Pg transition interval and secondly on problems concerning mainly the planktic foraminiferal taxonomy of the pioneer Globigerinids originated at the Danian. 


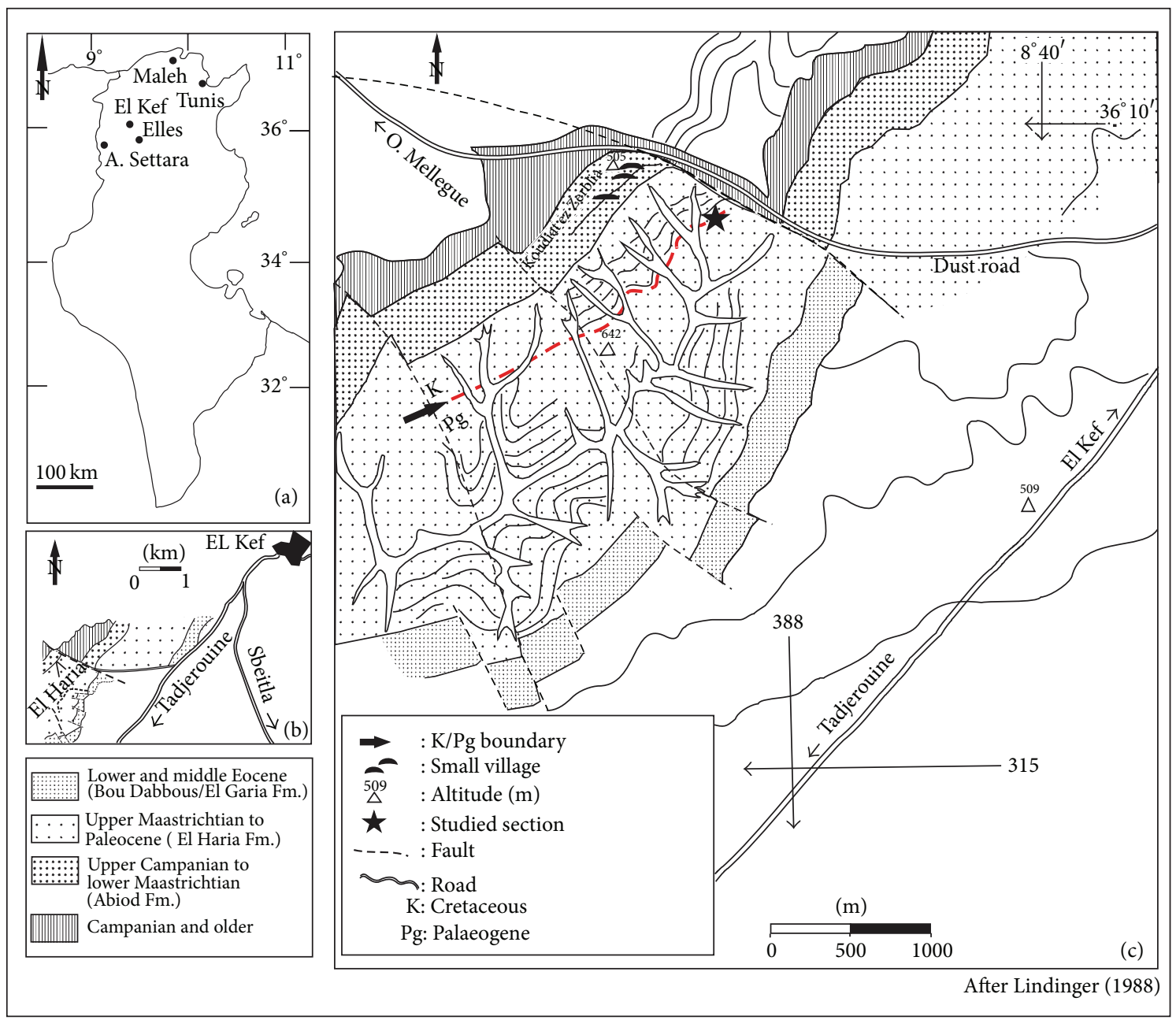

FIGURE 1: Geographical and geological location of the El Kef section in Tunisia, modified from Lindinger [1]. (a) General map of Tunisia, (b) map of El Kef area, and (c) detailed map of the section.

Consequently many species are proposed; other species are emended or discussed.

The planktic foraminiferal zonations and biochronology of the upper Maastrichtian-lower Danian of the middle and lower latitudes are still hotly debated. Whereas the Abathomphalus mayaroensis zone is used as a standard subdivision in the upper Maastrichtian, the proposed Danian zonation is still highly controversial. The suggested evolutionary pattern and diversification of planktic foraminifers across the $\mathrm{K} / \mathrm{Pg}$ boundary interval depend on the sampling resolution and the taxonomy of the early globigerinids that originated at the base of the Danian.

In order to elucidate the biostratigraphy at the K/Pg boundary in tropical, subtropical, and temperate latitudes and to correlate between these different area, we have studied several sections across these latitudes. The most expanded and continuous sections studied are El Kef and Ellès in Tunisia, Agost and Caravaca in Spain, and Bidart in France.

These sections are among the best documented and most complete and continuous sections known to date. The principal features of the K/Pg event (Ir anomaly, spinels, etc.) and the expanded lower Danian planktic foraminiferal zones and subzones are recorded in them $[13,15]$. The Global Stratotype Section and Point (GSSP) for the base of the Danian was defined near El Kef, Tunisia [15, 27]. The sections of Ellès (Tunisia), Caravaca and Agost (Spain), and Bidart (France), in which the K/Pg boundary event is well recorded, have been proposed to be auxiliary sections for the definition of the K/Pg boundary [13, 14, 28].

In this paper, based on high-resolution biostratigraphy, we attempt to check if these sections are complete, to present our contribution to the general discussion on the standard biozonation of the uppermost Maastrichtian and Danian stratigraphic interval $[5,7-10,16,17,24-26,29-32]$ and to correlate between these different standard biozones and subzones.

\section{Materials and Methods}

2.1. El Kef Stratotype Section. The GSSP site is located at a distance of between 5 and $6 \mathrm{~km}$ from the crossroad of the El Kef city. It can be reached by taking the exit towards 


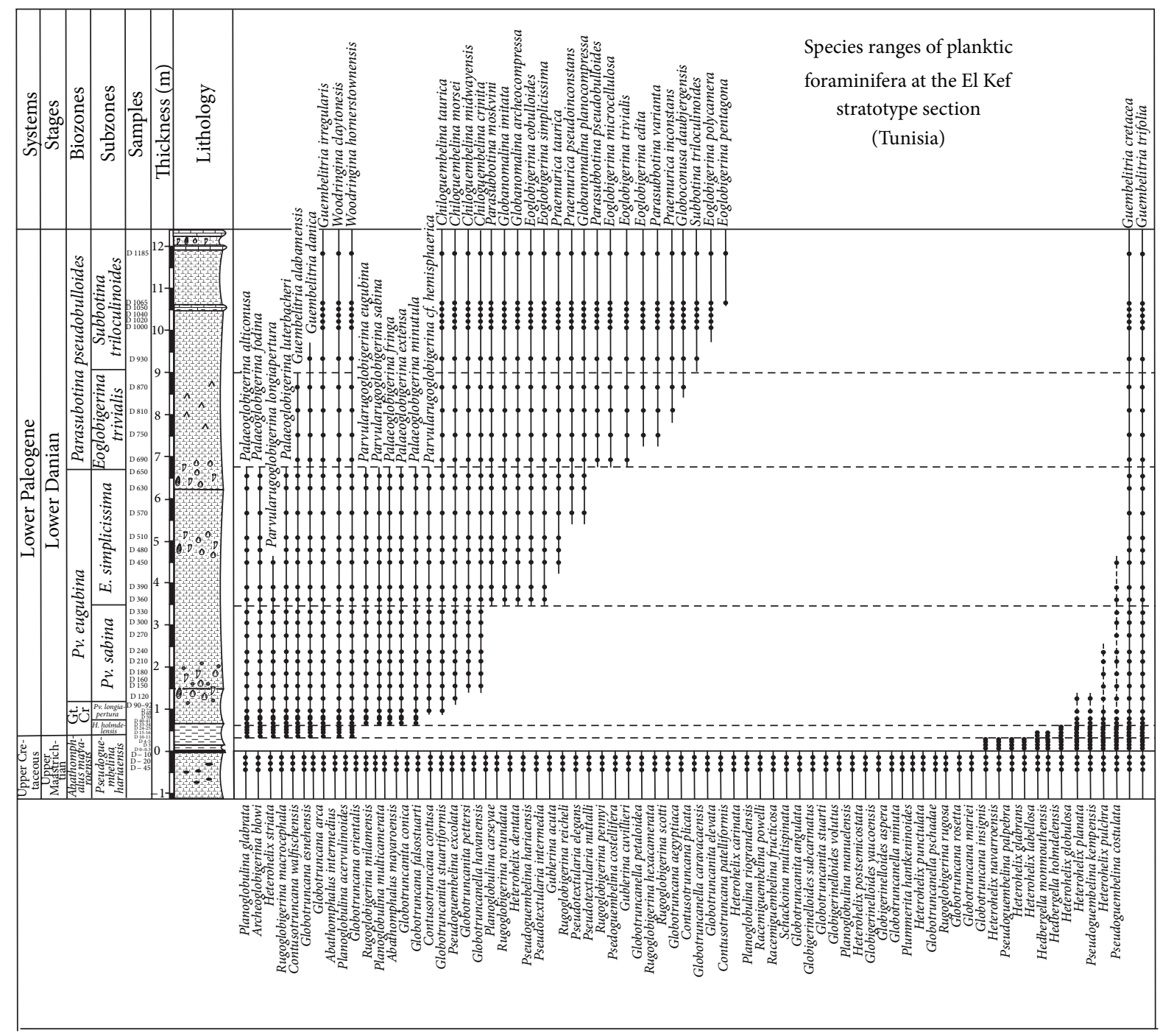

FIgURE 2: Species distributions of planktonic foraminifera in the El Kef stratotype section (Tunisia).

the town of Tajerouine and following the road which leads to Hammam Mellegue between a small village and a recent artificial lake. The GSSP lies in the upper Maastrichtian to Paleocene El Haria Formation, which is underlain by the upper Campanian/lower Maastrichtian Abiod Formation and overlain by the lower and middle Eocene Bou Dabbous/El Garia Formation (attributed to the Metlaoui Formation in the original proposal) (Figure 1).

The precise coordinates were measured with a GPS; Lambert coordinates calibrated from Carthago point: $\mathrm{N} 36^{\circ} 09^{\prime}$ $13.2^{\prime \prime}$, E008 $38^{\prime}$ 54.8' ${ }^{\prime \prime}$, UTM coordinates: N32, N4001314, E468675. Consequently, the Global Stratotype Section and Point for the base of the Danian, which by def-inition is also the base of the Paleocene, the Paleogene, the "Tertiary" and the Cenozoic, has been officially reestablished at the base of the boundary clay (see [27]).

The GSSP for the base of the Danian was defined in the El Kef section (Tunisia) and ratified by the IUGS in 1991. However, this GSSP was not officially published in a prestigious stratigraphical journal of wide distribution. Only a short note was published in Episodes by Cowie et al. [33], in a report on activities of the ICS from 1984 to 1989. Since then, certain problems have arisen as the detailed proposal was unknown to many scientists working on the $\mathrm{K} / \mathrm{Pg}$ boundary, new sections in Mexico were found, and controversial interpretations were proposed. Therefore, in order to resolve these problems, the ICS has required the ISPS to finally publish the proposal. On the 6th of April 2006, the chairman of ISPS (E. Molina) in collaboration with our Tunisian group visited the GSSP at El Kef again, in order to put in place an artificial marker ("golden spike") and to request the Tunisian authorities to protect the site. At the same time, the present status of the site has been documented by a series of photographs. Finally, it was officially published, see Molina et al. [27, 28].

The GSSP lies in the upper Maastrichtian to Paleocene El Haria Formation, which is underlain by the upper Campanian/lower Maastrichtian Abiod Formation and overlain 

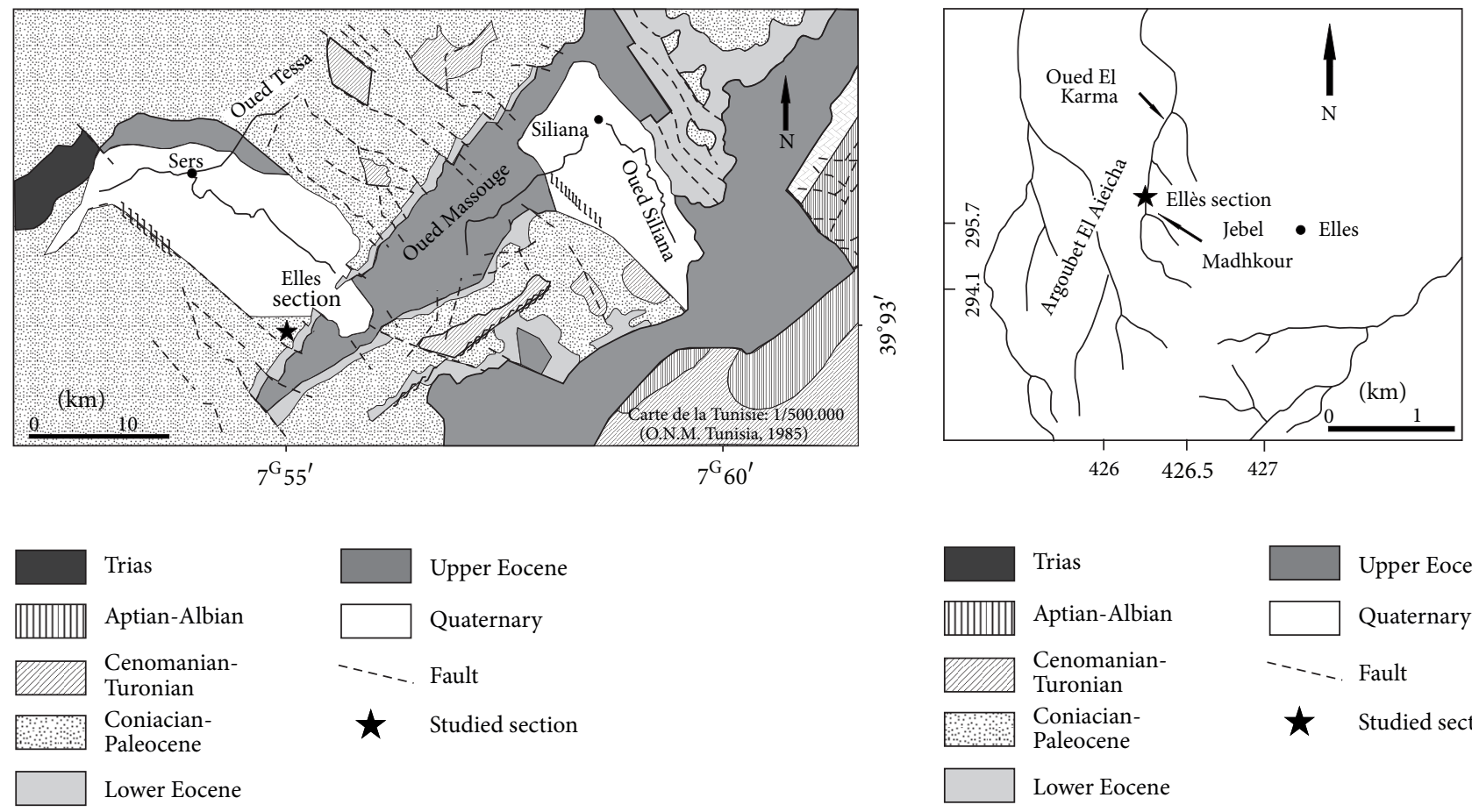

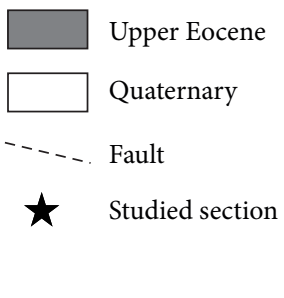

(a)
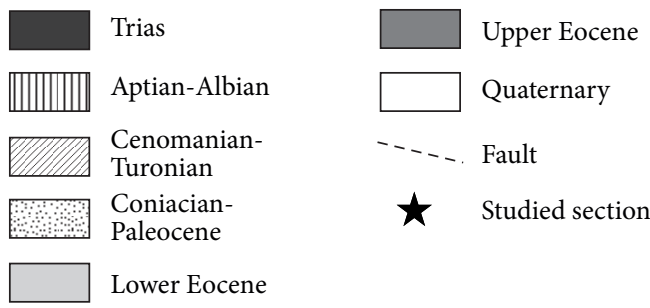

(b)

Figure 3: Geographical and geological location of the Ellès section (Tunisia). (a) Geological setting of the studied section, (b) geographical location of Ellès area.

by the lower and middle Eocene Bou Dabbous/El Garia Formation (attributed to the Metlaoui Formation in the original proposal).

In order to detail the Cretaceous-Paleogene (K-Pg) transition interval at the El Kef stratotype section, 41 samples are picked across $12.5 \mathrm{~m}$ thick interval deposition; $0.5 \mathrm{~m}$ of this interval are from the uppermost Maastrichtian (D-45 - D0$0,3)$ and $12 \mathrm{~m}$ from the lower Danian (D3-D1185). The samples D160, D180, D510, and D650 of lower Danian interval are very rich in corals, brachiopods, and bivalve of millimetric size [15].

The uppermost $0.5 \mathrm{~m}$ of the Maastrichtian is characterized by white-gray marls with abundant jarosite; the lower Danian is characterized by $2-3 \mathrm{~mm}$ of rusty layer (D0-0,3) superposed by $0.5 \mathrm{~m}$ of black clay, which corresponds to the boundary clay [15, 27], $0.5 \mathrm{~m}$ of dark gray clay, $1 \mathrm{~m}$ of gray, and $10 \mathrm{~m}$ of white-gray clayey marls.

\subsection{Ellès Section (Tunisia). This section is located in Central} Tunisia, $75 \mathrm{~km}$ southeast of El Kef K/Pg GSSP, between Houch El Balti and the village of Ellès, and $3 \mathrm{~km}$ east of Ellès (Figure 2). Its geographical coordinates are latitude $35^{\circ} 56^{\prime}$ $40.4^{\prime \prime} \mathrm{N}$ and longitude $9^{\circ} 4^{\prime} 49.9^{\prime \prime} \mathrm{E}$. The K/Pg transition is continuous and well exposed along the northwestern side of the Ellès syncline and is included into the El Haria Formation marls (Figure 3).

In 1978, Said-Benzarti described the Ellès section in her doctoral thesis, studied the upper Maastrichtian and Paleocene microfossils (planktic and benthic foraminifera and ostracods) and concluded that the K/Pg transition is continuous. Karoui-Yaakoub et al. [34] pointed out that the thin layer of the $\mathrm{K} / \mathrm{Pg}$ boundary is rich in microscopic glassy spheres. In 1998 these authors confirmed, with the collaboration of Rocchia and Robin, that the rust-colored layer is rich in Ir and Ni-rich spinel crystals. In 1999, a highresolution sampling was carried out by Karoui-Yaakoub in her doctoral thesis. The author detailed the $\mathrm{K} / \mathrm{Pg}$ transitions and confirmed that the $\mathrm{K} / \mathrm{Pg}$ transition at the Ellès section is continuous. The ostracods were studied by Said-Benzarti [35] and the nannofossils by Gardin [19].

The K/Pg planktic foraminifera were also studied by Arz et al. [36]. The section was also studied in detail by Zaghbib-Turki et al. [32, 37], recognizing the relevant event of the $\mathrm{K} / \mathrm{Pg}$ boundary and proposing it as parastratotype. Furthermore, Karoui-Yaakoub et al. [38] revised this section and concluded that the K/Pg interval is complete and similar to the El Kef section. Another section (Ellès II), located at $100 \mathrm{~m}$ toward the south, was described by Keller et al. [39], who analysed the paleoecology of the K/Pg boundary mass extinction based on planktic foraminifera.

The planktic foraminifera at this section were studied in detail by Gallala [15]. To detail the planktic foraminiferal species ranges at Ellès section, 58 samples are picked across $16.5 \mathrm{~m}$ thick interval deposition. $1 \mathrm{~m}$ of this interval is from the uppermost Maastrichtian (EN-90-EN-2-0), and $15.5 \mathrm{~m}$ are from the Danian (EN5-EN1550).

The Maastrichtian deposits consist of gray shales and marly shales below the $\mathrm{K} / \mathrm{Pg}$ boundary. This boundary is well marked by a $2-3 \mathrm{~mm}$ thick rusty red layer (EN0-0,2) which contains altered spherules, spinels, and anomalous 


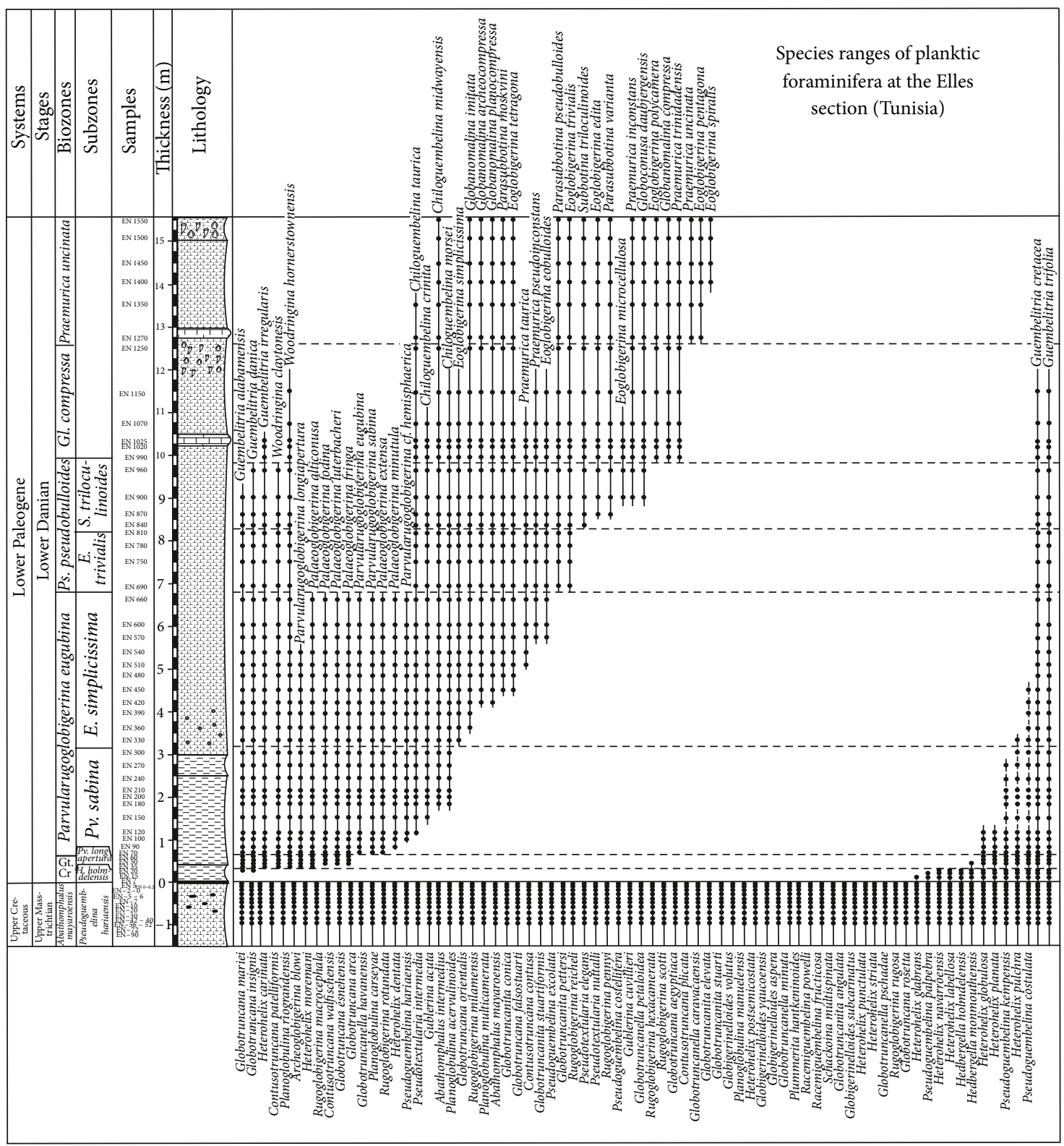

FIGURE 4: Species distributions of planktonic foraminifera in the Ellès section (Tunisia).

concentrations of iridium [32, 40]. Above this interval, the basal Danian consists of a 50-60 cm thick dark gray to black claystone layer followed by $2.5 \mathrm{~m}$ of light gray claystone and $12 \mathrm{~m}$ of dark to light gray marls intercalated in the upper part of the Danian interval by $20-30 \mathrm{~cm}$ thick of gray limestone. This upper part is rich in corals, brachiopods, and bivalves of millimetric size (samples EN1250 and EN 1550) [15] (Figure 4).

2.3. Agost and Caravaca Section (Spain). The Agost and Caravaca sections are located in the Betic Cordillera of southeastern Spain. The section of Agost is placed about $1 \mathrm{~km}$ northeastern of Agost village (Alicante region), at $\mathrm{km} 13$ of the road Agost-Castalla. Its geographical coordinates are latitude $38^{\circ} 27^{\prime} \mathrm{N}$ and longitude $0^{\circ} 38^{\prime} \mathrm{W}$. The Agost section is about $100 \mathrm{~km}$ to the east of the Caravaca section with a similar lithology (e.g., [9]).

The section of Caravaca is placed about $3 \mathrm{~km}$ southwestern of the town of Caravaca (Figure 5). The Caravaca section is located in South Spain (Murcia region), about $3 \mathrm{~km}$ south of the town of Caravaca in the Barranco del Gredero ravine (Figure 5). Its geographical coordinates are latitude $39^{\circ} 5^{\prime} 19^{\prime \prime} \mathrm{N}$ and longitude $1^{\circ} 52^{\prime} 26^{\prime \prime} \mathrm{W}$.

The Caravaca section lies in the Betic Cordillera, Subbetic zone, and the K/Pg boundary is in the Jorquera Formation, composed of gray marls and claystone. In 1975, Abtahi initially studied the foraminifera in his master thesis. Smit $[41,42]$ found that the K/Pg boundary claystone was more 

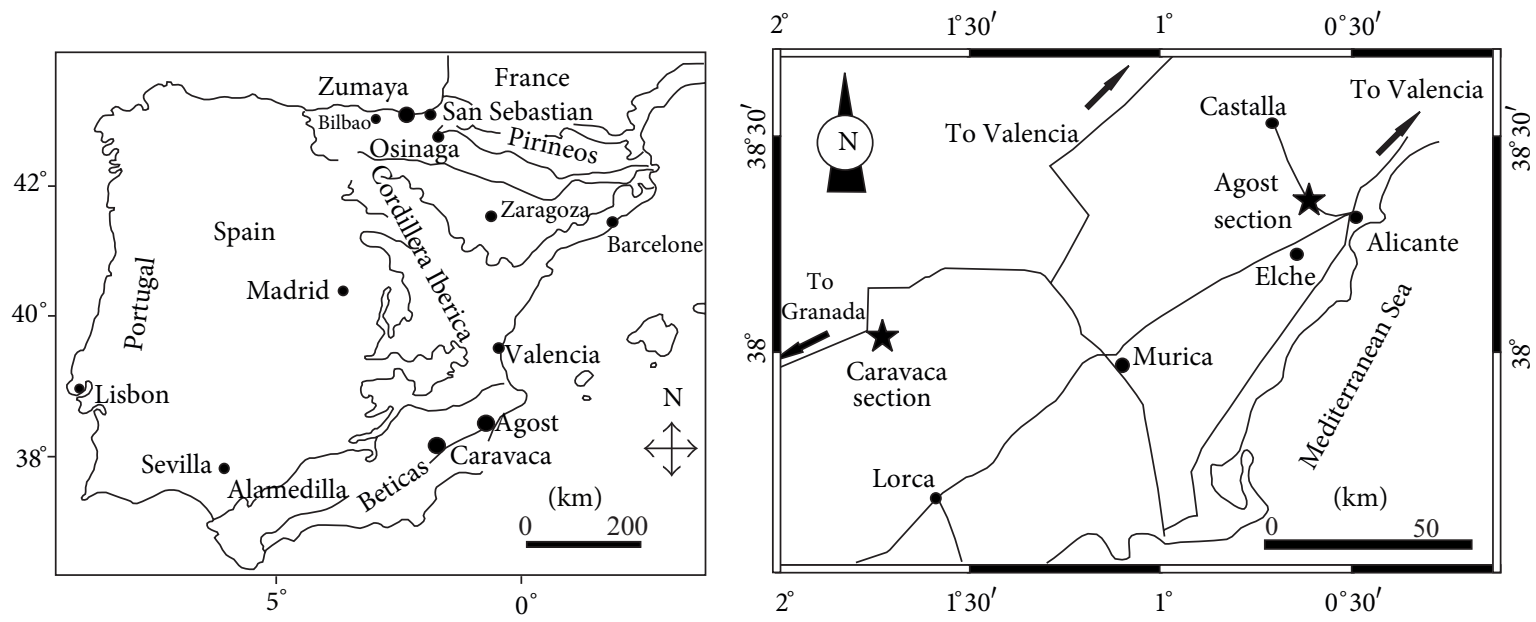

Figure 5: Geographical location of the Caravaca and Agost sections located in Betic Cordillera (Spain).

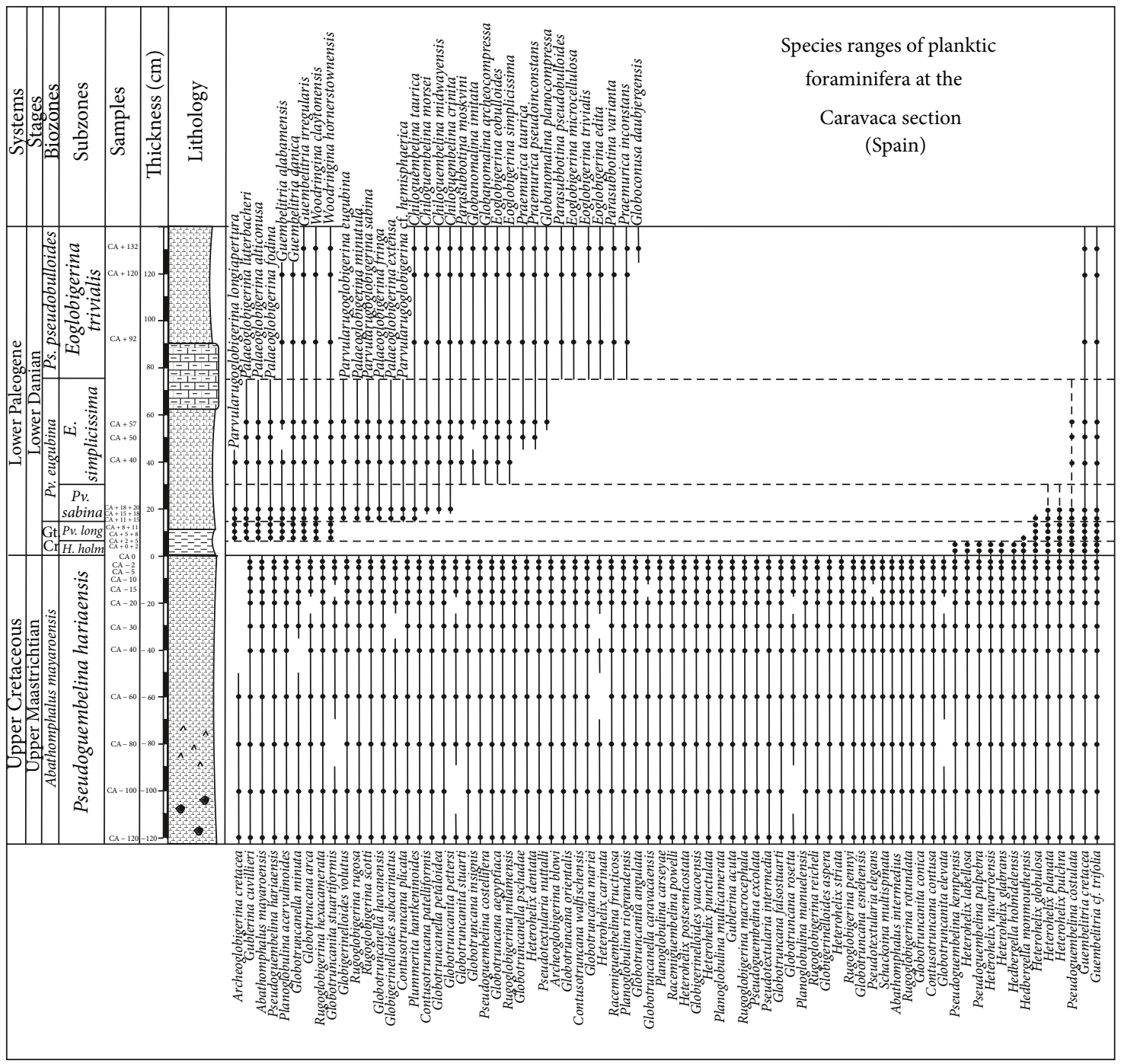

FIGURE 6: Species distributions of planktonic foraminifera in the Caravaca section (Spain). 


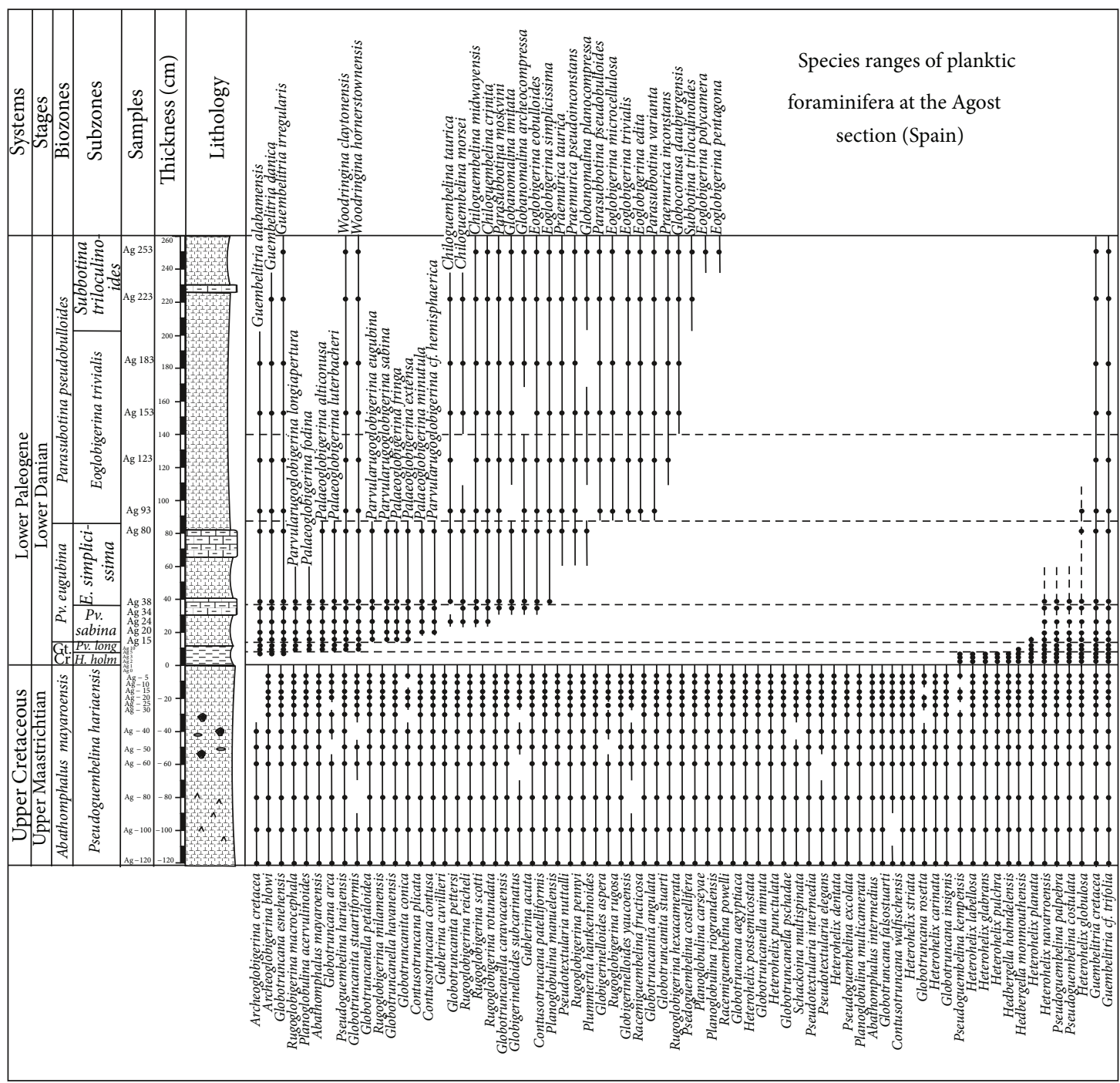

FIGURE 7: Species distributions of planktonic foraminifera in the Agost section (Spain).

expanded than in the Gubbio section (Italy) and discovered a planktic foraminiferal association between the Abathomphalus mayaroensis zone and the Pv. eugubina zone, which he called Gt. cretacea zone. Later, Smit and Hertogen [43] identified a $2-3 \mathrm{~mm}$ thick rusty red layer and the Ir anomaly. Their study was published one month before the seminal paper by Alvarez et al. [44], although they did not claim priority because the theory was previously communicated in a congress in 1979 by the Alvarez team. The red rusty layer also contains altered microtektites [45] as well as anomalous concentrations in $\mathrm{Co}, \mathrm{Cr}, \mathrm{Ni}, \mathrm{As}, \mathrm{Sb}$, and Se [46]. Many other mineralogical and geochemical analyses were accomplished finding overwhelming meteoritic impact evidence [47-57].

The planktic foraminifera at this section were studied in detail by Canudo et al. [9], Kaiho and Lamolda [58], Arz et al. [31], and Gallala [15]. A geologically instantaneous extinction event in small benthic foraminifera was also documented at the K/Pg boundary by Coccioni et al. [59] and Coccioni and Galeotti [60] in the Caravaca section. A temporary faunal turnover, consisting of the reorganization of the benthic foraminiferal community structure, but with no mass extinction in the small benthic foraminifera, has been reported from this section [59, 61]. The calcareous nannoplankton was studied by Gardin and Monechi [18] concluding that Cretaceous species occurring after the K/Pg boundary are mainly reworked. Furthermore, bioturbation across the boundary clay has been reported by RodríguezTovar and Uchman [62], which is the cause of the Cretaceous nannofossils and foraminifers reworked in the lowermost Paleogene.

The two Betic sections are similar, although the Caravaca sedimentation rate in the lower Danian is around twice that of Agost. The K/Pg boundary in both sections is marked by a thin $10 \mathrm{~cm}$ black clay layer with a basal $2 \mathrm{~mm}$ thin rust-red layer containing an Ir anomaly and other impact evidence, such as altered microtektites [7]. The sections of Agost and Caravaca have a similar lithology of gray marls and 


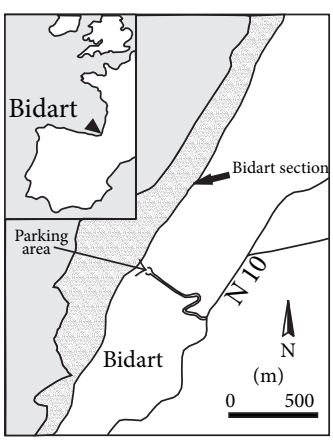

(a)

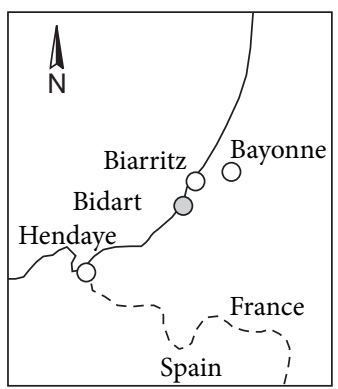

(b)

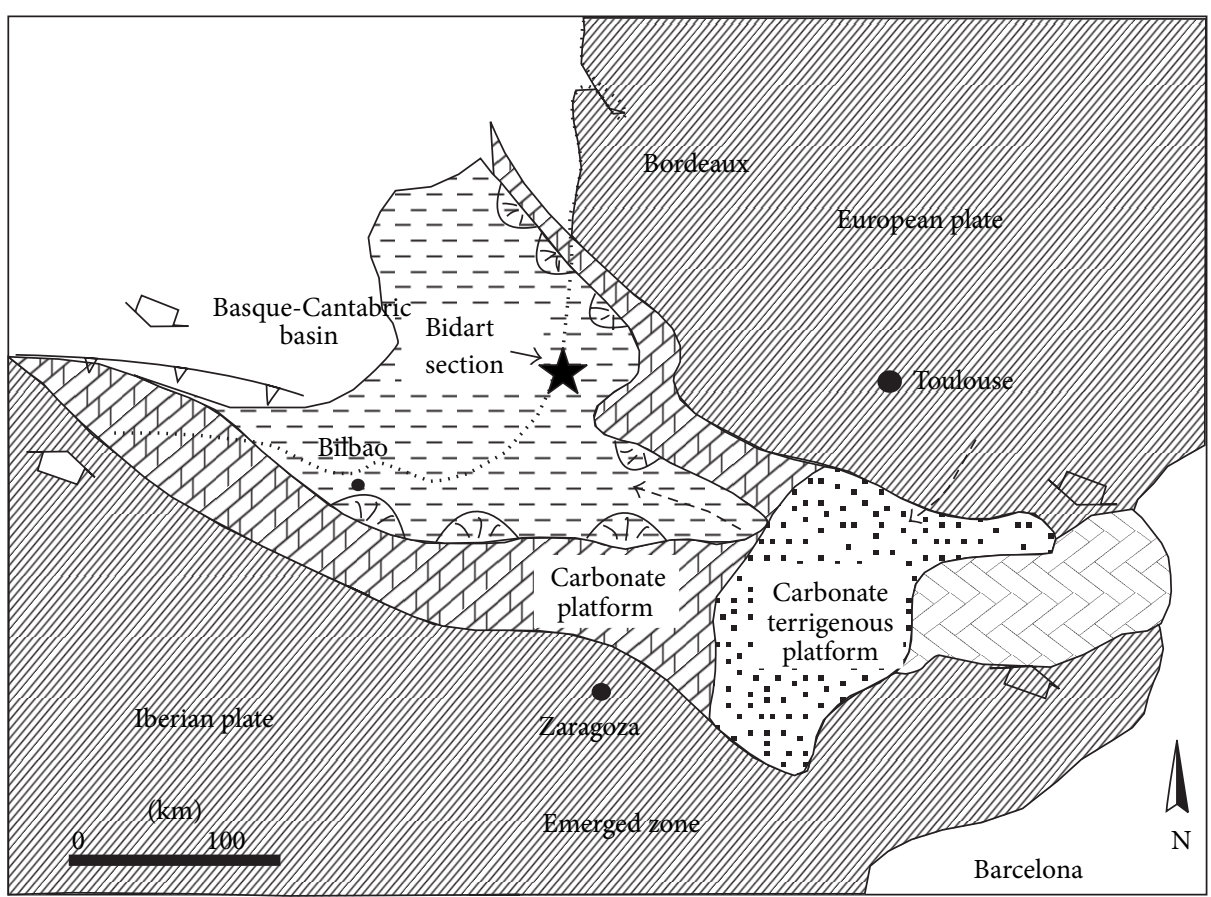

....... Current coastline

$\searrow$ Eocene compression

<-- Siliciclastic inflow

$\checkmark \nabla$ Paleo-subduction front

ए) Deep-sea fan

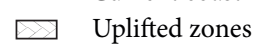

(c)

Figure 8: Geographical (a-b) and Paleogeographical setting (c) of the Bidart section located in the Pyrenean domain during the Paleocene (from [2]).

calcareous marls [9] and have been considered as some of the most continuous land-based K/Pg sections (e.g., [20]). The planktic foraminifera at this section were studied in detail by Gallala [15]; 25 samples are picked across $2.6 \mathrm{~m}$ thick interval deposition at Caravaca section (Spain). About $1.2 \mathrm{~m}$ of this interval corresponds to the uppermost Maastrichtian (CA120-CA-2) containing abundant tracks of Zoophycus [15], the sample CA0 is picked at the $\mathrm{K} / \mathrm{Pg}$ boundary corresponding to the rusty layer, and $1.4 \mathrm{~m}$ was sampled at the lower Danian interval (from the sample $\mathrm{CA}+0+2$ to the sample $\mathrm{CA}+132$ ) (Figure 6).

The Agost section was first described by Leclerc [63], who documented the planktonic foraminiferal faunas and argued that the sedimentation was essentially continuous from Santonian to Eocene. Since then, the Agost section has been studied by numerous authors (e.g., [10, 15, 64-67]) who analysed the biostratigraphy of planktonic foraminifera. Most of these authors are of the opinion that planktonic foraminifera underwent a catastrophic mass extinction at the $\mathrm{K} / \mathrm{Pg}$ boundary $[10,66,68]$, but some interpret the extinction as more gradual $[9,67]$. The benthic foraminifera was studied by Pardo et al. [67], Alegret et al. [69], and Gallala [15].

The Maastrichtian deposits consist of pelagic gray massive marls with interbedded calcareous marls; the latter are rare or absent in the uppermost Maastrichtian. These marly deposits which contain abundant ostracodes and foraminifera belong to the upper part of the Quipar-Jorquera Formation, originally described by van Veen [70]. The Quipar-Jorquera Formation is Cenomanian to Eocene in age [71] and shows similar characteristics across the Inner Prebetic. The K/Pg boundary lies within Chron 29R [65] and is marked by a sharp contact between the Maastrichtian marls and a $10 \mathrm{~cm}$ thick layer of black claystone (Ag0-Ag10), with a 2-3 mm thick, red, ferruginous level at its base. This layer marks the K/Pg boundary at Agost [10]. Twenty-nine samples are picked, in this work, across $3.8 \mathrm{~m}$ thick interval deposition at Agost section (Spain). About $1.2 \mathrm{~m}$ of this interval was picked from the uppermost Maastrichtian (sample Ag120 to Ag5) containing zoophycus tracks [15], Ag0 from the rusty layer, and $2.6 \mathrm{~m}$ thick from the lower Danian (Ag1-Ag253) (Figure 7).

2.4. Bidart Section (France). The Bidart section is located in southwestern France, within the Basque-Pyrenean Basin between Hendaye and Biarritz villages, on the Bidart beach named Pavillon Royal or Caseville, where the upper Cretaceous-Eocene outcrops are well exposed on the beach of Bidart (Figure 8). This section is easily accessible by 


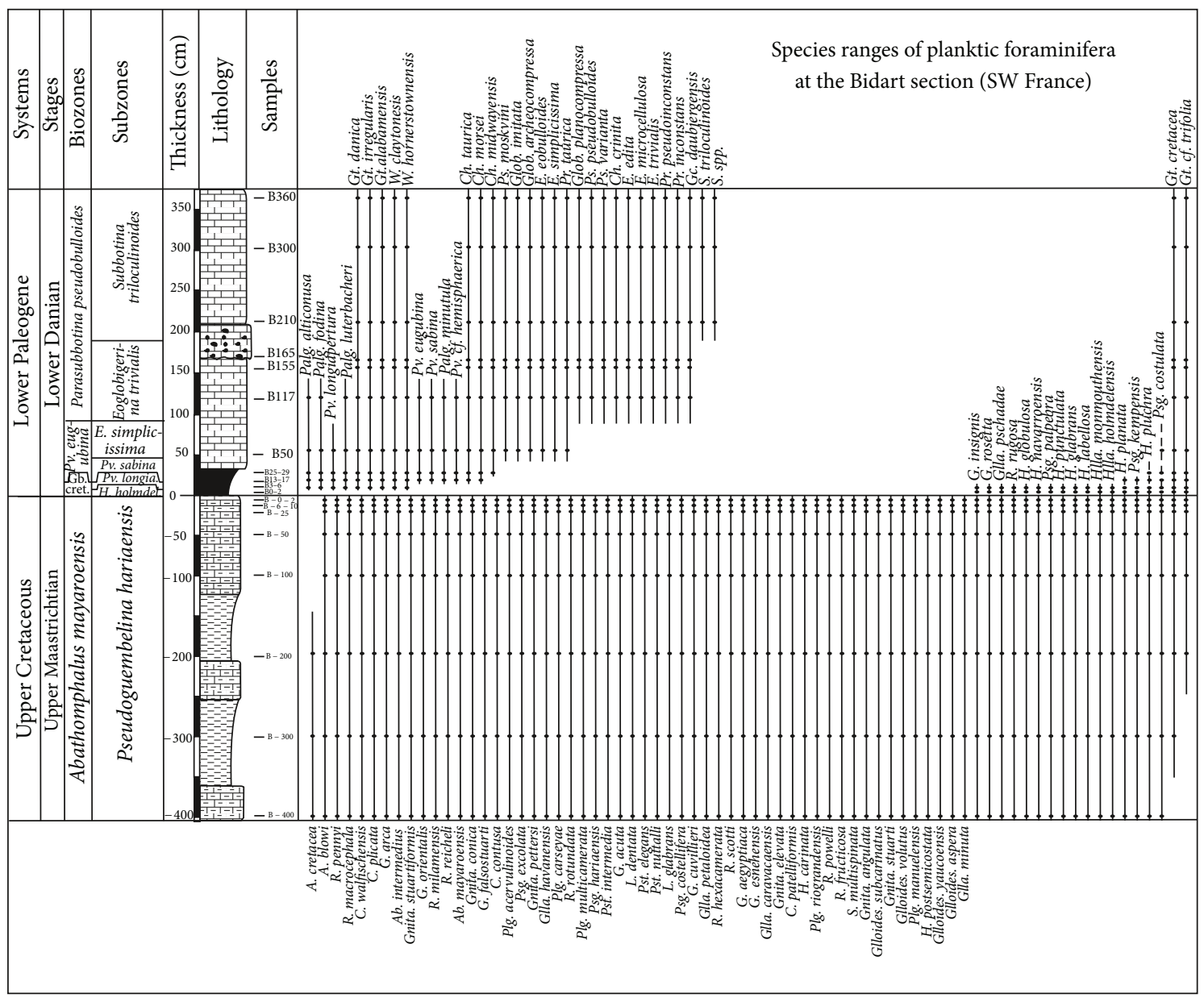

FIGURE 9: Species distributions of planktonic foraminifera in the Bidart section (France).

the national road $\mathrm{n}^{\circ} 10$, at about $2 \mathrm{~km}$ north of the Bidart village. Its geographical coordinates are latitude $43^{\circ} 26^{\prime} 54^{\prime \prime}$ $\mathrm{N}$ and longitude $1^{\circ} 35^{\prime} 16^{\prime \prime} \mathrm{W}$.

The Bidart section (located in southwestern France) together with the Zumaya section (northern Spain) is one of the most complete European $\mathrm{K} / \mathrm{Pg}$ boundary sections exposed in the Atlantic margin [72, 73].

The well-exposed Cretaceous-Paleogene nearby the Bidart beach has interested many authors. The Bidart section was initially investigated by means of calcareous nannofossils by Martini [74] and by Lézaud in his doctoral thesis in 1967. It has been also studied by numerous authors from different points of view such as stable isotope analysis [75-77], Ir content [46, 78], biostratigraphy (e.g., [13-15, 78-80]), sedimentology [81], magnetostratigraphy [82, 83], geochemistry [76, 78, 84], and chronostratigraphy [83]. Detailed biostratigraphical studies across the K/Pg interval were based on calcareous nannofossils (e.g., [72, 85, 86]), confirming the continuous deposition record at the Bidart section, and on planktic foraminifera [13-15, 73, 87, 88]. Its macrofaunal content (ammonites and inoceramids) was studied by Ward [89] and Ward and Kennedy [90]. Benthic foraminiferal assemblages across the $\mathrm{K} / \mathrm{Pg}$ boundary indicate deposition in the upper-middle part of the slope and reflect mesotrophic conditions during the late Maastrichtian and a strong decrease in the food supply to the sea floor coincident with the K/Pg boundary [15, 22].

The uppermost Maastrichtian deposits at the Bidart section consist of metric thick marls and clayey limestones alternations containing abundant foraminifers and scarce echinoids. The uppermost $2 \mathrm{~cm}$ Maastrichtian deposits are gray soft marls. The K/Pg boundary is marked by a $2 \mathrm{~mm}$ thick rusty layer. The lowermost Danian deposits which contrast with those of the Maastrichtian consist of $6 \mathrm{~cm}$ dark clays. The overlying rocks consist of brownish claystone, thin laminated dark gray marls, and pink and white limestones. Into these limestones, a mass flow deposits with a clear erosive basal surface and breccia occur between $1.6 \mathrm{~m}$ and $2.10 \mathrm{~m}$ above the $\mathrm{K} / \mathrm{Pg}$ boundary rust layer.

Below and above the K/Pg boundary layer, the marls contrast sharply. Those of the uppermost Maastrichtian are light gray marls, and those of the lowermost Danian $(6 \mathrm{~cm}$ thick) are dark clays. The K/Pg boundary layer corresponds to a $2 \mathrm{~mm}$ thick of rust deposits with a positive Ir anomaly $[46,78,84]$ and Ni-spinel enrichment [40]. This rust layer is overlain by $6 \mathrm{~cm}$ of brownish claystone which marks 


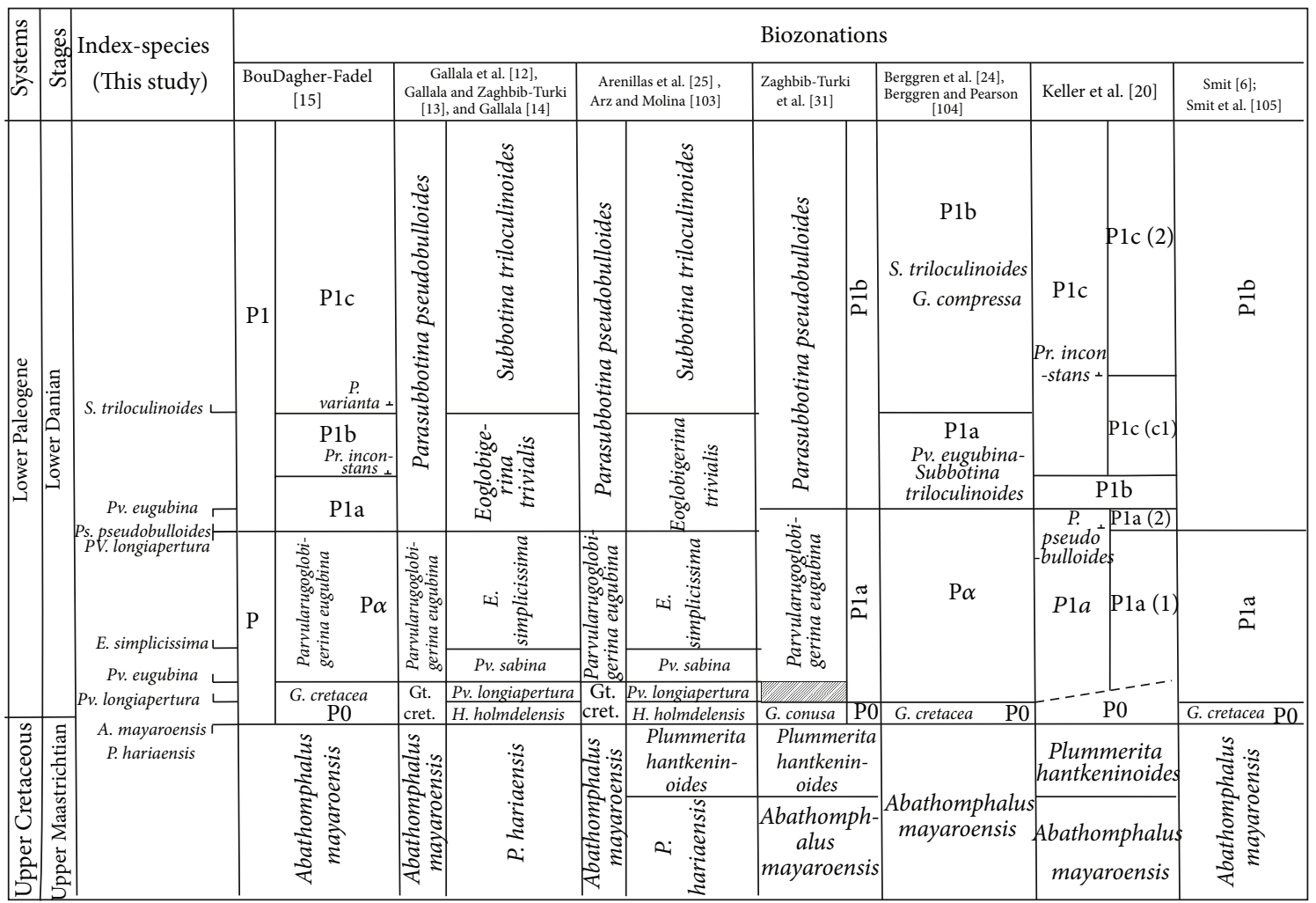

FIGURE 10: Correlation between the proposed uppermost Maastrichtian and lowermost Danian planktic foraminiferal biozonations.

the boundary layer, then and towards the top, by thinly laminated dark gray claystone. Consequently, across the lowermost Danian, the clays dominate over the carbonates.

For this study, we collected 19 samples in an interval including $4 \mathrm{~m}$ of the uppermost Maastrichtian below the $\mathrm{K} / \mathrm{Pg}$ boundary (samples B $400 \mathrm{~cm}$ to B $0-2 \mathrm{~cm}$ ) and $3.60 \mathrm{~m}$ of the lowermost Danian overlying the $\mathrm{K} / \mathrm{Pg}$ rusty layer (samples B 0-2 cm to B $360 \mathrm{~cm}$ ).

All the samples picked in the Tethyan and Atlantic sections in this work are irregularly spaced, being a detailed sampling of the upper Maastrichtian and lower Danian and a high resolution sampling across the K/Pg boundary. Close to the $\mathrm{K} / \mathrm{Pg}$ boundary in the uppermost Maastrichtianlowermost Danian $50 \mathrm{~cm}$ thick interval, the samples are spaced at $2-10 \mathrm{~cm}$ intervals, although below and above, the samples are less close and are mostly spaced at $10-50 \mathrm{~cm}$ intervals. The preservation of the planktic foraminifers of the studied sections is generally good. All the soft clayey or marly samples were disaggregated in water with diluted $\mathrm{H}_{2} \mathrm{O}_{2}$, and those of limestone were soaked in acetic acid diluted solution (80\%) for 6 hours and then washed through a $63 \mu \mathrm{m}$ sieve. All the samples were dried in an oven at $50^{\circ} \mathrm{C}$. The specimens of the planktic foraminifers identified are equal to $63 \mu \mathrm{m}$ or larger than this size fraction (Figure 9).

\section{Biostratigraphy}

At the Tethyan (El Kef stratotype and Ellès in Tunisia and Agost and Caravaca in Spain) and Atlantic sections (Bidart in
France), the planktonic foraminifers are often well preserved, very abundant, and diversified. All the biozones and subzones are easily recognized by their biomarkers (Figure 10). Across the K-Pg transition, four standard biozones are recognized. Using high-resolution sampling, these zones are detailed and subdivided in subzones.

3.1. Abathomphalus mayaroensis Zone. As defined by Bolli [5], this biozone corresponds to the taxon range interval of the nominate species. It has been recognized by many authors in the Tethyan area and elsewhere $[7,9,10,13-15,17,29,31,91-$ 98].

This biomarker remains omnipresent up to the top of the Maastrichtian. Moreover, no apparent hiatus exists at the El Kef section (Tunisia), Agost and Caravaca sections (Spain). We have identified the Plummerita hantkeninoides subzone which is the most common and persistent species across the uppermost Maastrichtian. This species is absent at middle latitudes: Bidart section (SW France) and Zumaya section (Spain) [13-15, 36, 68]. Previously, several authors used this small-sized species $(<150 \mu \mathrm{m})$ as the biomarker of the latest Maastrichtian nominate zone [9, 21]. Nevertheless, Keller [99] working on the high-latitude K-Pg transition deposits (sites 738C, 752B, and 690C) noted the absence of Plummerita hantkeninoides. Consequently, if this species was considered absent at the middle- and high-latitude areas, it would be restricted to low latitudes [13-15]. 


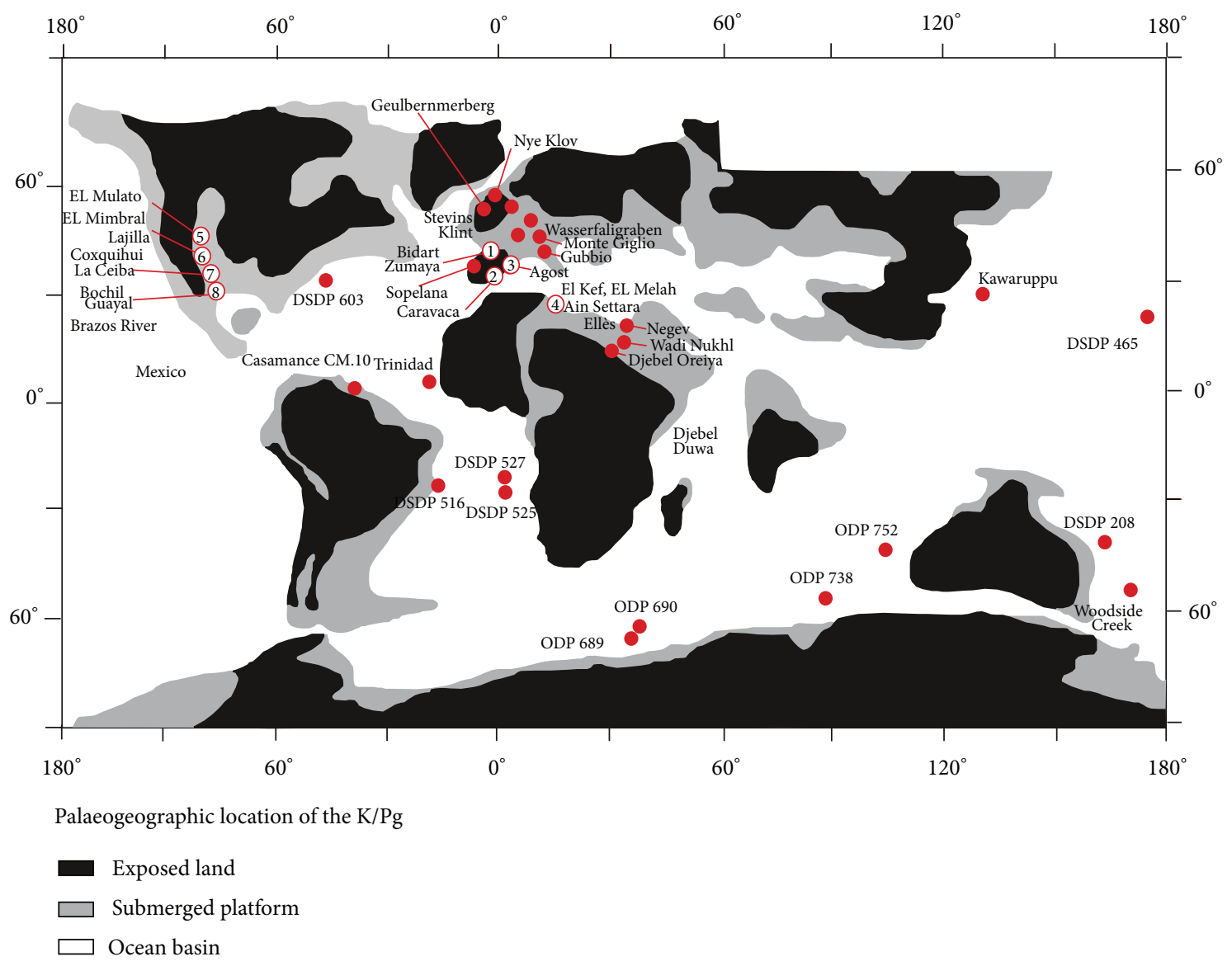

FIGURE 11: Paleolatitudinal and paleogeographic location of the correlated sections: the El Kef GSSP (Tunisia) and the auxiliary sections, Ellès (Tunisia), Agost, and Caravaca (Spain) located at the Tethys Ocean, and Bidart (SW France) and Zumaya (Spain) located at the Atlantic Ocean (after [3]).

3.2. Guembelitria cretacea Zone. This zone was initially defined by Smit [7, 41]. It spans the biostratigraphic interval characterized by the partial range of the nominate taxon, between the last appearance datum (LAD) of Cretaceous taxa (Abathomphalus, Globotruncana, Gansserina, Pseudoguembelina, among others) at the $\mathrm{K} / \mathrm{Pg}$ boundary as delineated by the essentially global iridium spike and the first appearance datum (FAD) of Parvularugoglobigerina eugubina. In this paper, following Arenillas et al. [26, 100], we take in account that Parvularugoglobigerina longiapertura and Parvularugoglobigerina eugubina are two valid species occurring shift FAD. Its magnetostratigraphy position is in Chron C29r, and its duration is between 65.000 and $64.981 \mathrm{Ma}$ (after $[12,25]$ : A) or between 65.500 and $65.478 \mathrm{Ma}$ (after Röhl et al., 2001 [101]: B). At the stratotype $\mathrm{K} / \mathrm{Pg}$ boundary section and GSSP point El Kef section, Ellès section as well as at Caravaca and Agost sections, and Bidart section, the Parvularugoglobigerina longiapertura FAD is prior to the Parvularugoglobigerina eugubina FAD $[10,26]$. We subdivide the Gt. cretacea zone into two subzones: (1) Hedbergella holmdelensis subzone, characterising the interval between the K/Pg boundary and the FAD of Parvularugoglobigerina longiapertura; (2) Parvularugoglobigerina longiapertura subzone, corresponding to the interval between the FAD of Parvularugoglobigerina longiapertura and the FAD of Parvularugoglobigerina eugubina.

3.3. Parvularugoglobigerina eugubina Zone. This zone was defined by Luterbacher and Premoli Silva [4] and identified as the Globigerina eugubina (=Parvularugoglobigerina eugubina in this paper) zone. It corresponds to the biostratigraphical interval characterized by the total range of the nominate taxon. It corresponds to the later part of Chron C29r. Its estimate age is between 64.981 and $64.945 \mathrm{Ma}(\mathrm{A})$ or between 65.478 and $65.436 \mathrm{Ma}(\mathbf{B})$.

We subdivide the Pv. eugubina subzone into two subzones which are, respectively, the Palaeoglobigerina sabina subzone and Eoglobigerina simplicissima subzone. The oldest one (i.e., Parvularugoglobigerina sabina), as defined previously [26], corresponds to the interval between the FAD of Parvularugoglobigerina eugubina and the FAD of Eoglobigerina simplicissima. In this paper, we emend the youngest one (i.e., Eoglobigerina simplicissima) which becomes corresponding to the interval between the FAD of the nominate taxon to the LAD of the Pv. eugubina. 


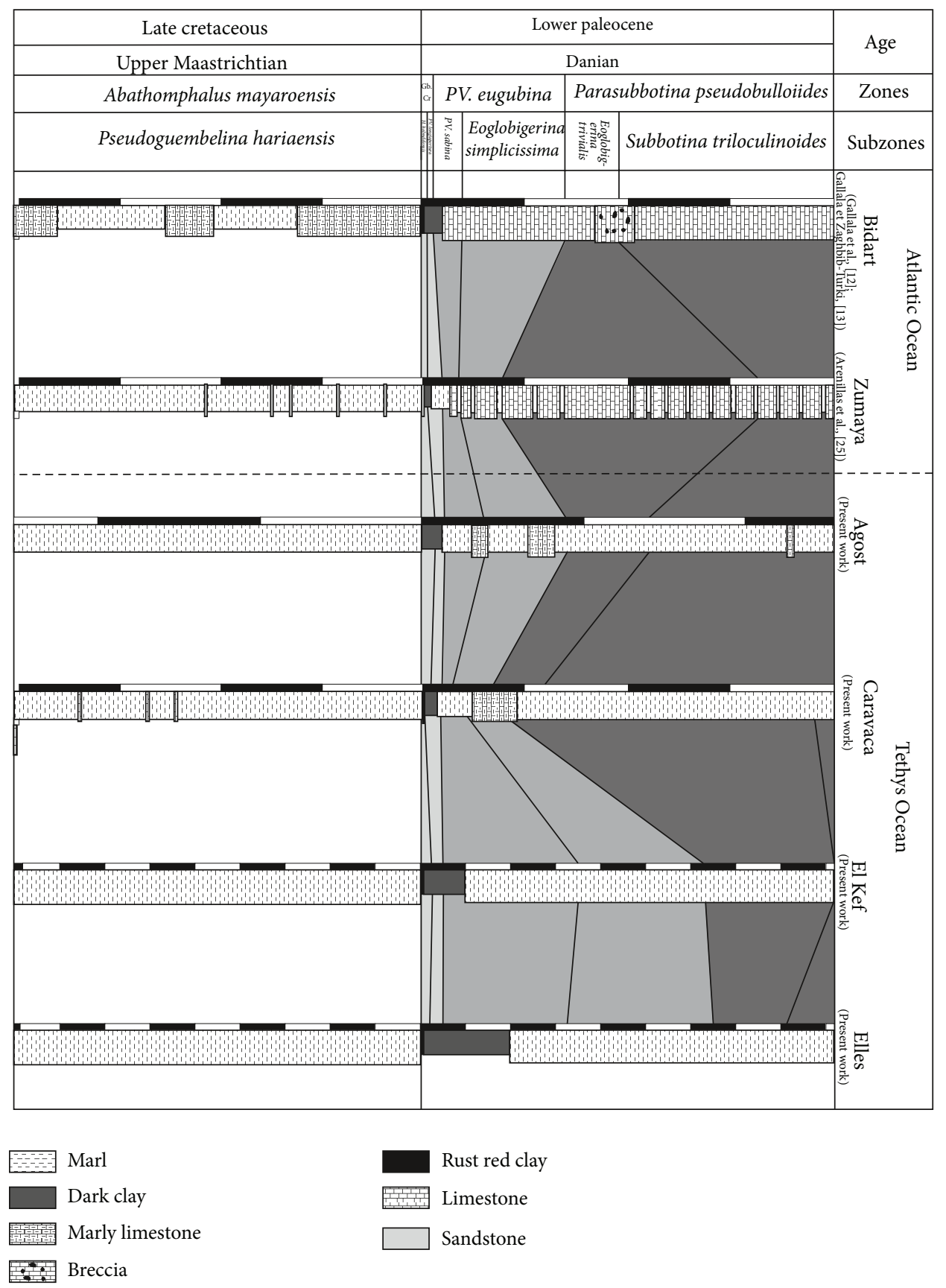

Figure 12: Correlation between complete Cretaceous-Paleogene transition interval low latitude sections: El Kef and Ellès (Tunisia), Caravaca and Agost (Spain) and the middle latitude sections: Bidart (France) and Zumaya (Spain).

3.4. Parasubbotina pseudobulloides Zone. Initially, Leonov and Alimarina [102] proposed Globigerina pseudobulloidesG. daubjergensis zone, and then Bolli [5] shortened this name. It corresponds to the interval between the LAD of Pv. eugubina and the FAD of Globanomalina compressa. It differs slightly from the Parasubbotina pseudobulloides proposed by Molina et al. [10] and adopted by Arenillas et al. $[17,26,100]$ especially at its base as discussed above. We remind that at the El Kef section (Tunisia), Agost and Caravaca sections (Spain), the LAD of Parvularugoglobigerina eugubina, and the FAD of Parasubbotina pseudobulloides are simultaneous.

Following Arenillas et al. [26], we subdivide the Parasubbotina pseudobulloides zone into the Eoglobigerina trivialis and Subbotina triloculinoides subzones. The older subzone (Eoglobigerina trivialis) corresponds to the interval between the LAD of Parvularugoglobigerina eugubina and the FAD of Subbotina triloculinoides. The younger one (Subbotina triloculinoides) spans the interval between the FAD of Subbotina triloculinoides and the FAD of Globanomalina compressa. 


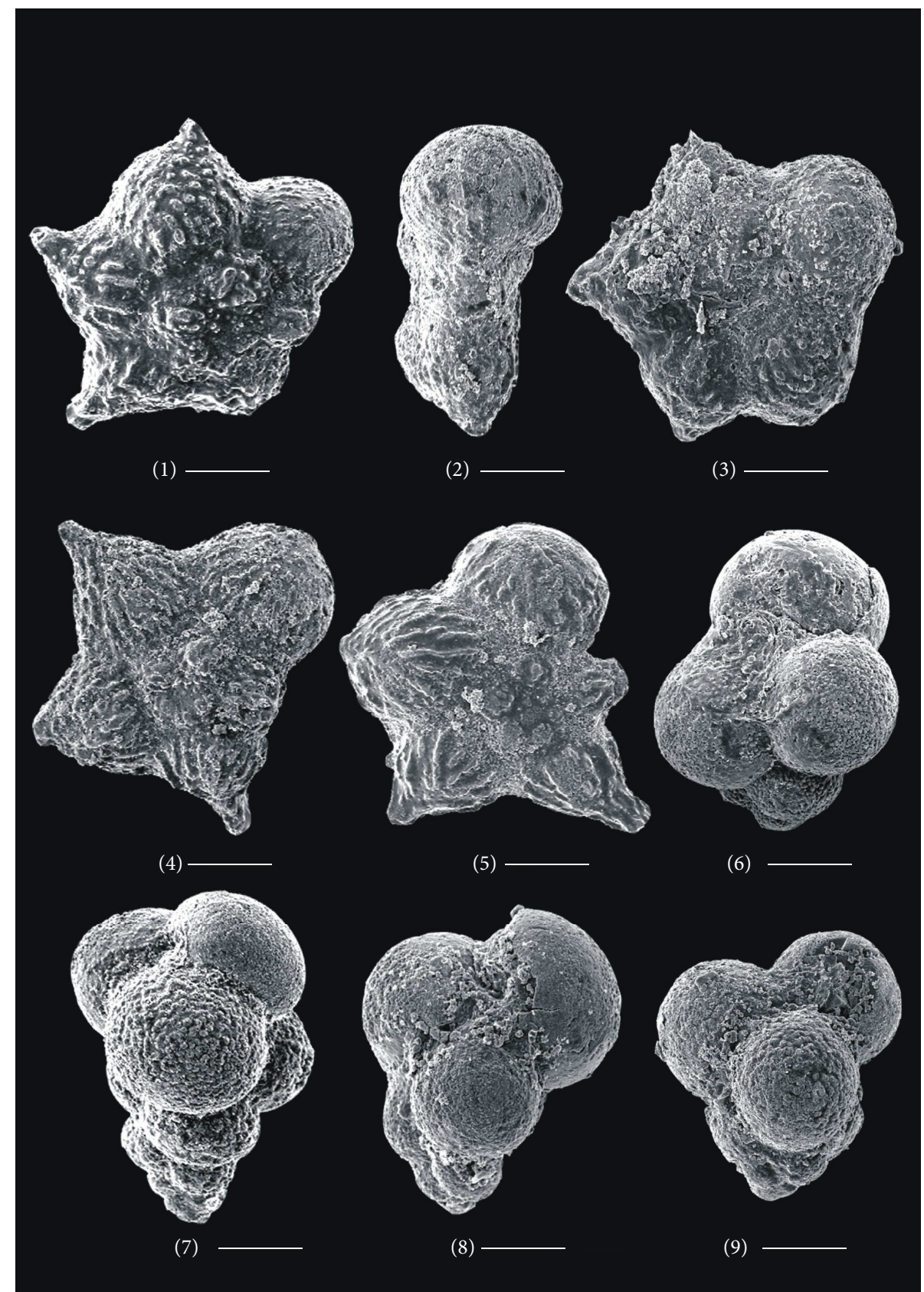

FIGURE 13: Scale bars $=100 \mu \mathrm{m}$. (1-5) Plummerita hantkeninoides (Brönnimann), Upper Maastrichtian. (6) Globoconusa daubjergensis (Brönnimann), Danian. (7) Guembelitria irregularis (Morozova), Danian. (8) Guembelitria cretacea (Cushman), Danian. (9) Guembelitria trifolia (Morozova), Danian.

\section{Correlation}

Based on high-resolution biostratigraphy analysis, the El Kef (K/Pg boundary stratotype section and GSSP point) and Ellès sections in Tunisia, the Agost and Caravaca sections (Betic Cordillera, Spain), and the Bidart section (France) have a complete stratigraphic record across the CretaceousPaleogene transition. These coeval sections may be compared with their neighbours in the Atlantic and Tethyan realms and may be considered auxiliary sections (Figure 11).
At the Tethys and Atlantic realms, all the biozones and subzones are easily recognized by their biomarkers (Figure 10). At the Tethyan realm, Plummerita hantkeninoides, commonly indicative of the uppermost Maastrichtian, is present, and it is associated to Pseudoguembelina hariaensis. However, Plummerita hantkeninoides is absent at the Bidart and Zumaya sections located in middle latitudes of the Atlantic realm. The Atlantic realm contains diverse planktonic foraminifers; among them is Pseudoguembelina hariaensis which had a larger paleogeographical distribution 


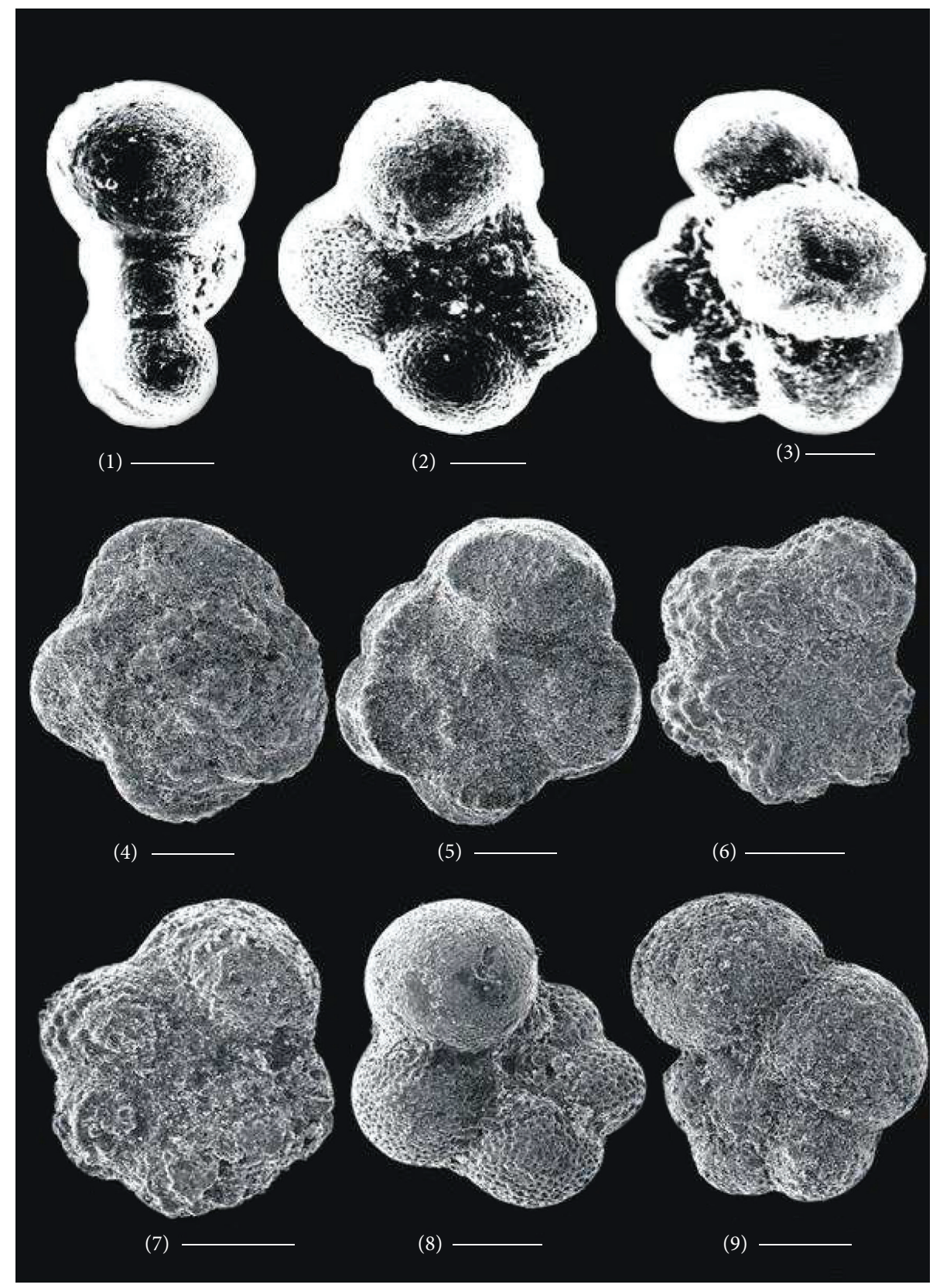

FIGURE 14: Scale bars $=100 \mu \mathrm{m}$. (1-2) Parasubbotina pseudobulloides (Plummer), Danian. (3) Praemurica pseudoinconstans (Subbotina), Danian. (4-5) Abathomphalus mayaroensis (Bolli), Upper Maastrichtian. (6-7) Hedbergella holmdelensis (Olsson), Danian. (8-9) Parvularugoglobigerina sabina [4], Danian.

being recorded both in the Tethys and the Atlantic paleoceans. It is more relevant to be considered as the marker species of the nominate uppermost Maastrichtian subzone instead of Plummerita hantkeninoides (Figure 13).

Consequently, we replaced Plummerita hantkeninoides by Pseudoguembelina hariaensis as index species. This is recorded both in the Tethys and Atlantic realm; it indicates the uppermost Maastrichtian subzone.

At El Kef section, the Guembelitria cretacea biozone spans $55 \mathrm{~cm}$. It is more expanded than at Agost $(12,5 \mathrm{~cm})$, Caravaca
$(15 \mathrm{~cm})$ relative to the Tethys realm, and Bidart $(10 \mathrm{~cm})[13-$ 15], and Zumaya [26, 100], relative to Atlantic realm. It is nearly as expanded as at Ellès section in Tunisia $(65 \mathrm{~cm})$.

In spite of the reduced Guembelitria cretacea biozone expansion at El Kef $\mathrm{K} / \mathrm{Pg}$ boundary stratotype and the auxiliary sections, Caravaca and Agost sections (Spain), like elsewhere (at the Bidart and Zumaya sections), and the Ellès section (Tunisia), the Parvularugoglobigerina longiapertura FAD is observed at the upper part of the relevant biozone (Figure 12). 


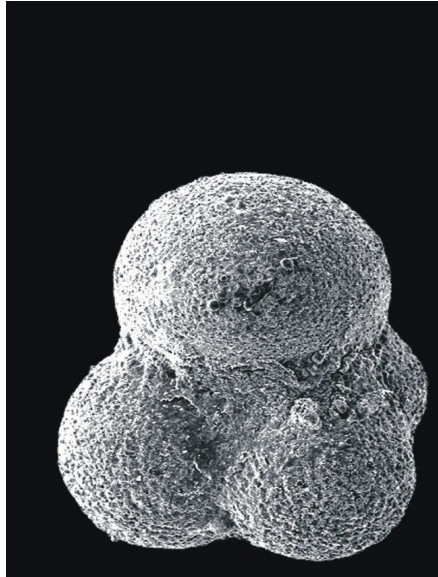

(1)

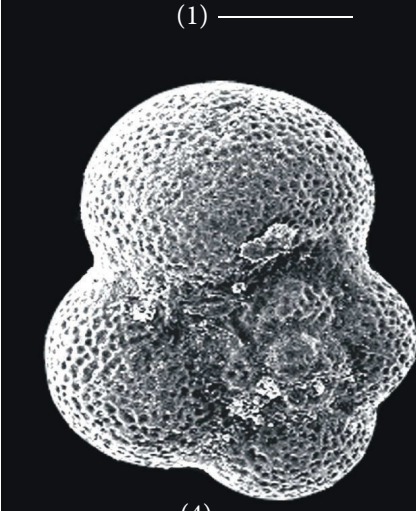

(4)

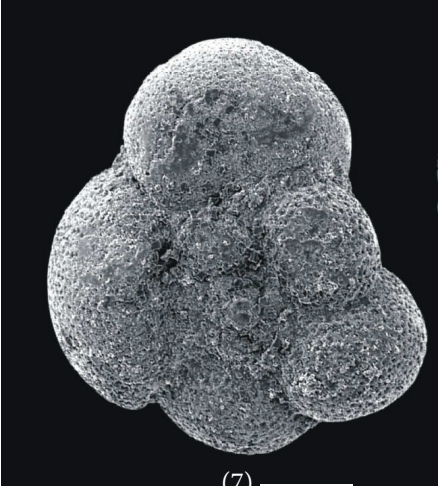

(7)

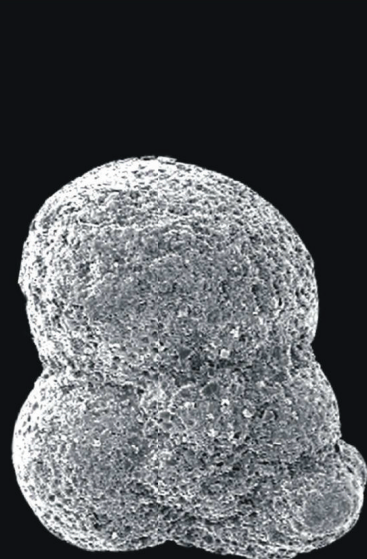

(2)

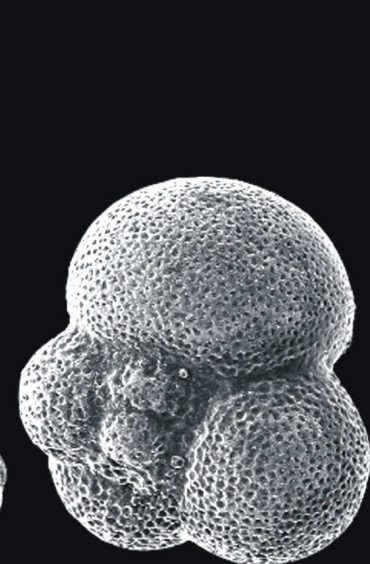

(3)

-

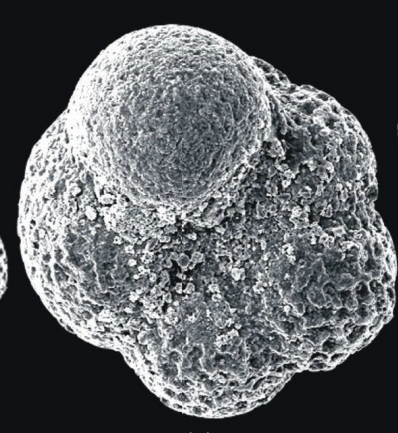

(5)

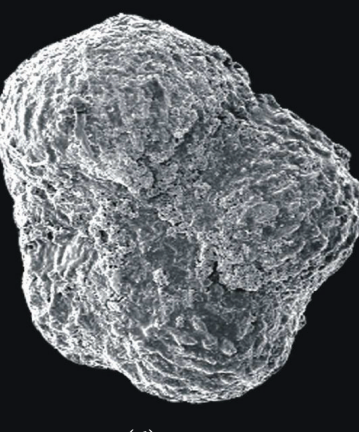

(6)

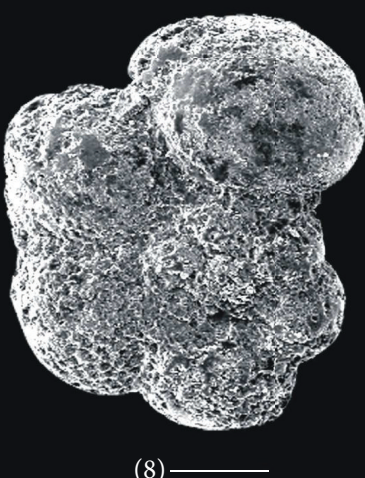

(8)

Figure 15: Scale bars $=100 \mu \mathrm{m}$. (1-2): Subbotina triloculinoides (Plummer). Danian. (3-4): Eoglobigerina trivialis (Subbotina). Danian. (5-6): Eoglobigerina simplicissima (Blow). Danian. (7-8): Praemurica inconstans (Subbotina). Danian. (9): Parasubbotina pseudobulloides (Plummer). Danian.

At the El Kef section, the Parvularugoglobigerina eugubina zone spans $5.7 \mathrm{~m}$. It is more expanded than at Caravaca and Agost sections ( $42 \mathrm{~cm}$ and $65 \mathrm{~cm}$, resp.). It is also more expanded than at the Zumaya section (Spain) which spans $63 \mathrm{~cm}[26,100]$ and the Bidart section (SW France), spanning $107 \mathrm{~cm} \mathrm{[13].} \mathrm{However,} \mathrm{it} \mathrm{is} \mathrm{approximately} \mathrm{equivalent}$ to the Ellès section $(5.8 \mathrm{~m})$. This zone is subdivided into the Parvularugoglobigerina sabina (Figure 14) and Eoglobigerina simplicissima subzones (Figures 6 and 15). The deposition thickness of the zones and subzones at the El Kef stratotype section and Ellès section is more expanded than at the ones at Agost and Caravaca (Spain) and at Bidart (France). This would be related to a largest deposition ratio and/or to the sedimentary basin morphology.

In summary, El Kef section (K/Pg boundary stratotype section and GSSP point) and Ellès section in Tunisia, Agost and Caravaca sections (Betic Cordillera, Spain), relative to the Tethyan realm (low latitude), and Bidart section (France) relative to the Atlantic realm (middle latitude) are complete sections containing all the zones and subzones characterizing the upper Maastrichtian-lower Paleogene interval without any hiatus. The Ellès, Agost, and Caravaca sections may 
be proposed as auxiliary sections of low latitude like the Bidart section for middle latitude.

\section{Conclusion}

A high-resolution biostratigraphic analysis carried out at El Kef (K/Pg boundary stratotype section and GSSP point) and Ellès sections in Tunisia, Agost and Caravaca sections (Betic Cordillera, Spain) in the Tethys realm (low latitude), and Bidart section in the Atlantic realm (middle latitude) confirms the completeness and continuity of the stratigraphic record across the K-Pg transition. All the planktic foraminiferal zones and subzones, characterizing the uppermost Maastrichtian-lower Danian interval, are well defined including the Abathomphalus mayaroensis zone (ended by Pseudoguembelina hariaensis subzone indicating the uppermost Maastrichtian), the Guembelitria cretacea zone (subdivided into Hedbergella holmdelensis and Parvularugoglobigerina longiapertura subzones), the Parvularugoglobigerina eugubina zone (subdivided into Parvularugoglobigerina sabina and Eoglobigerina simplicissima Subzones), and the Ps. pseudobulloides zone (subdivided into Eoglobigerina trivialis and Subbotina triloculinoides subzones) for the lower Danian. These zones and subzones are easily recognized by their well preserved biomarkers.

The Gt. cretacea zone in the Bidart section is less expanded than at El Kef and Ellès, but nearly equal to the equivalent zone in the Zumaya, Agost, and Caravaca sections in Spain. Despite its reduced thickness, it is relatively complete, as suggested by the FAD of $P v$. longiapertura in its upper part, similarly as in the El Kef $\mathrm{K} / \mathrm{Pg}$ boundary stratotype section and other auxiliary sections. The Pv. eugubina zone is $107 \mathrm{~cm}$ thick. Although it is thinner than in El Kef $(5.7 \mathrm{~m})$ and Ellès $(5.8 \mathrm{~m})$, it is thicker than in the Caravaca and Agost sections ( $42 \mathrm{~cm}$ and $65 \mathrm{~cm}$, resp.). The E. trivialis subzone of the Ps. Pseudobulloides zone is less expanded than in the Agost, Caravaca, El Kef, or Ellès sections. In the Bidart section, only the lower part of the $S$. triloculinoides subzone was studied herein, still below the FAD of Gl. compressa. The deposition thicknesses of the zones and subzones at the El Kef and Ellès sections are more expanded than at the Agost and Caravaca sections (Spain) and the Bidart section (France). This could be related to the higher deposition rates and/or to the sedimentary basin morphology.

In summary, these sections (Agost, Caravaca, Bidart, and Ellès) possess a complete uppermost Maastrichtian-earliest Paleogene record, as documented by planktic foraminifers in this work. Although they are much less expanded than the El Kef stratotype section, they may be very useful auxiliary sections of the boundary interval for the Tethyan and the Atlantic realms.

\section{Acknowledgments}

This research was funded by the Spanish Ministerio de Educación y Ciencia (DGICYT Project CGL2007-63724/BTE, and AECI Project A/4845/06), the Aragonian Departamento de Educación y Ciencia (DGA group E05), Ministère de l'Enseignement Supérieur et de la Recherche Scientifique (Tunisia), and by the Research Unit "Dynamique des Bassins Sédimentaires, Paléoenvironnements \& Structures Géologiques" (GEODPS) of Faculty of Science, Department of Geology (Tunis) Tunisia. The author thanks Professor Mohamed Moncef Turki for his support and Professor Dalila Zaghbib-Turki for her constructive suggestions. The author is also grateful for the support and help of the Spanish collegues during the field trip in Tunisia, Spain, and France and at the laboratory; Professor Eustoquio Molina (Ex-Presidente of the International Subcommission on Paleogene Stratigraphy), Professor José Antonio Arz, and Professor Ignacio Arenillas, from the University of Zaragoza, for their support and correction. The author is very grateful to the native of English Richard Stephenson for the improvements of the final version of their paper. The author thanks anonymous reviewers delegated by the Paleontology Journal and the Editor Professor Marcelle BouDagher-Fadel for their suggestions allowing them to improve our paper.

\section{References}

[1] M. Lindinger, The Cretaceous/Tertiary boundaries of El Kef and Caravaca: sedimentological, geochemical and clay mineralogical aspects [Thesis ETH], 1988.

[2] V. Pujalte, J. Baceta, A. Payros, X. Orue-Etxebarria, and J. SerraKiel, GEP-IGCP 286, Field Sem, 1994.

[3] C. R. Denham and C. R. Scotese, Terra mobilis: A Plate Tectonic Program for the Macintosh, Geoimages, Austin, Tex, USA, 1987.

[4] H. P. Luterbacher and I. Premoli Silva, "Biostratigrafia del limite Cretaceo-Terziario nell'Appennino central," Rivista Italiana di Paleontologia, vol. 70, pp. 67-117, 1964.

[5] H. M. Bolli, "Zonation of Cretaceous to Pliocene marine sediments based on Planktonic foraminifera," Boletín Informativo de la Asociación VenezoLana de Geología Minera y Petrolera, vol. 9, no. 1, pp. 1-34, 1966.

[6] W. A. Berggren and R. D. Norris, Biostratigraphy, Phylogeny and Systematics of Paleocene Trochospiral Planktic Foraminifera, vol. 43 of Micropaleontology, supplement 1, 1997.

[7] J. Smit, "Extinction and evolution of planktonic foraminifera after a major impact at the Cretaceous/Tertiary boundary," Geological Society of America, vol. 190, pp. 329-352, 1982.

[8] G. Keller, "Extinction, survivorship and evolution of planktic foraminifera across the Cretaceous/Tertiary boundary at El Kef, Tunisia," Marine Micropaleontology, vol. 13, no. 3, pp. 239-263, 1988.

[9] J. I. Canudo, G. Keller, and E. Molina, "Cretaceous/Tertiary boundary extinction pattern and faunal turnover at Agost and Caravaca, S.E. Spain," Marine Micropaleontology, vol. 17, no. 3-4, pp. 319-341, 1991.

[10] E. Molina, I. Arenillas, and J. A. Arz, "The Cretaceous/Tertiary boundary mass extinction in planktic foraminifera at Agost, Spain," Revue de Micropaleontologie, vol. 39, no. 3, pp. 225-243, 1996.

[11] R. K. Olsson and C. Liu, "Controversies on the placement of Cretaceous-Paleogene boundary at the K/P mass extinction of planktonic foraminifera," Palaios, vol. 8, no. 2, pp. 127-139, 1993.

[12] R. K. Olsson, C. Hemleben, W. A. Berggren, and B. T. Huber, "Atlas of paleocene planktonic foraminifera," Smithsonian Contributions to Paleobiology, vol. 85, pp. 1-252, 1999. 
[13] N. Gallala, D. Zaghbib-Turki, I. Arenillas, J. A. Arz, and E. Molina, "Catastrophic mass extinction and assemblage evolution in planktic foraminifera across the Cretaceous/Paleogene (K/Pg) boundary at Bidart (SW France)," Marine Micropaleontology, vol. 72, no. 3-4, pp. 196-209, 2009.

[14] N. Gallala and D. Zaghbib-Turki, "High resolution biostratigraphy based on planktic foraminifera across the CretaceousPaleogene transition at the Bidart section (SW France)," Acta Geologica Polonica, vol. 60, no. 2, pp. 243-255, 2010.

[15] N. Gallala, Micropaléontologie, biostratigraphie, paléoécologie et environnements de dépôt des foraminifères planctoniques et benthiques du passage Crétacé-Paléogène en Tunisie, Espagne et France [Thèse de doctorat], 2010.

[16] F. BouDagher, "Biostratigraphic and geological significance of planktonic foraminifera," Developments in Palaeontology and Stratigraphy, vol. 22, pp. 1-301, 2012.

[17] I. Arenillas, J. A. Arz, and E. Molina, "El límite Cretácio/Tertciario de Zumaya, Osinaga y Músquiz (Pirineos): control bioestratigráfico y cuantitativo de hiatus con foraminíferos planctónicos," Revista de la Sociedad Geológica De España, vol. 11, no. 1-2, pp. 127-138, 1998.

[18] S. Gardin and S. Monechi, "Palaeoecological change in middle to low latitude calcareous nannoplankton at the Cretaceous/Tertiary boundary," Bulletin de la Societe Geologique de France, vol. 169, no. 5, pp. 709-723, 1998.

[19] S. Gardin, "Late Maastrichtian to early Danian calcareous nannofossils at Elles (Northwest Tunisia). A tale of one million years across the K-T boundary," Palaeogeography, Palaeoclimatology, Palaeoecology, vol. 178, no. 3-4, pp. 211-231, 2002.

[20] K. Perch-Nielsen, J. McKenzie, and Q. He, "Biostratigraphy and isotope stratigraphy and the "catastrophic" extinction of calcareous nannoplankton at the Cretaceous/Tertiary boundary," Geological Society of America, vol. 190, pp. 353-371, 1982.

[21] G. Keller, L. Li, and N. MacLeod, "The Cretaceous-Tertiary boundary stratotype section at El Kef, Tunisia: how catastrophic was the mass extinction?" Palaeogeography, Palaeoclimatology, Palaeoecology, vol. 119, no. 3-4, pp. 221-254, 1996.

[22] L. Alegret, M. A. Kaminski, and E. Molina, "Paleoenvironmental recovery after the Cretaceous/Paleogene boundary crisis: evidence from the marine Bidart Section (SW France)," Palaios, vol. 19, no. 6, pp. 574-586, 2004.

[23] N. Gallala, Etude des foraminifères benthiques de l'intervalle du passage Crétacé-Tertiaire des coupes d'Oued El Melah et d'El Aouena (Région de Sejnène, Tunisie): paléontologie [Paléoécologie Mastère], 2004.

[24] M. Toumarkine and H. P. Luterbacher, "Paleocene and Eocene planktic foraminifera," in Planktonic, Stratigraphy, H. M. Bolli, J. B. Saunders, and K. Perch-Nielson, Eds., pp. 88-153, Cambridge University Press, 1985.

[25] W. A. Berggren, D. V. Kent, C. C. Swisher III, and M. P. Aubry, "A revised paleogene geochronology and chronostratigraphy," in Geochronology, Time and Global Stratigraphic Correlation, W. A. Berggren, Ed., vol. 392, Society of Economic Geologist and Paleontologist, 1995.

[26] I. Arenillas, J. A. Arz, and E. Molina, "A new high-resolution planktic foraminiferal zonation and subzonation for the lower Danian," Lethaia, vol. 37, no. 1, pp. 79-95, 2004.

[27] E. Molina, L. Alegret, I. Arenillas et al., "The Global Boundary Stratotype Section and Point for the base of the Danian Stage (Paleocene, Paleogene, "Tertiary", Cenozoic) at El Kef, Tunisia-original definition and revision," Episodes, vol. 29, no. 4, pp. 263-273, 2006.
[28] E. Molina, L. Alegret, I. Arenillas et al., "The Global Boundary Stratotype Section and Point for the base of the Danian Stage (Paleocene, Paleogene, “Tertiary", Cenozoic): auxiliary sections and correlation," Episodes, vol. 32, no. 2, pp. 84-95, 2009.

[29] W. H. Blow, "A study of the morphology, taxonomy, evolutionary relationship and the stratigraphical distribution of some Globigerinidae (mainly Globigerinacea)," in The Cainozoic Globigerinida, E. J. Brill, Ed., vol. 3, pp. 1-1413, Leiden, The Netherlands, 1979.

[30] I. Arenillas and J. A. Arz, "Origen y filogenia de las primeras especies de foraminíferos planctónicos del Paleoceno basal, tras el límite Cretácio/Terciario," Actas De 125 Aniversario-XII Bienal De La Real Sociedad De España De Historia Natural, pp. 281-285, 1996.

[31] J. A. Arz, I. Arenillas, E. Molina, and R. Sepulveda, "La estabilidad faunística de los foraminíferos planctónicos en el Maastrichtiense superior y su extinción en masa catastrófica en el límite K/T de Caravaca, España," Revista Geológica de Chile, vol. 27, pp. 27-47, 2000.

[32] D. Zaghbib-Turki, N. Karoui-Yaakoub, H. Belayouni, R. Rocchia, and E. Robin, "Enregistrement des évènements remarquables de la limite Crétacé-Tertiaire dans la coupe d'Ellès (Tunisie)," Comptes Rendus de l'Académie des Sciences, vol. 331, pp. 141-149, 2000.

[33] J. W. Cowie, W. Ziegler, and J. Remane, "Stratigraphic commission accelerates progress, 1984 to 1989," Episodes, vol. 12, no. 2, pp. 79-83, 1989.

[34] N. Karoui-Yaakoub, R. Benzarti-Said, and D. ZaghbibTurki, "Le passage Crétacé-Tertiaire dans la coupe d'Ellès (Tunisie centro-septentrionale)," 12ème Colloque Africain de Micropaléontologie, 1994.

[35] R. Said-Benzarti, "Les ostracodes du campanien-supérieur à l'Yprésien de la coupe d'ellès (Tunisie du Centre-nord)," Biostratigraphie, Paléoécologie Et Paléogéographie, Bulletin Elf Aquitaine, vol. 20, pp. 197-211, 1998.

[36] J. A. Arz, I. Arenillas, E. Molina, and C. Dupuis, "Los efectos tafonómico y "Signor-Lipps" sobre la extinción en masa de foraminíferos planctónicos en el límite Cretácico/Terciario de Ellès (Tunicia)," Revista de la Sociedad Geológica de España, vol. 12, no. 2, pp. 251-267, 1999.

[37] D. Zaghbib-Turki, N. Karoui-Yaakoub, R. Benzarti-Said, R. Rocchia, and E. Robin, "Révision de la limite Crétacé-Tertiaire de la coupe d'Ellès (Tunisie centro-septentrionale). Proposition d'un nouveau stratotype," Geobios, vol. 34, no. 1, pp. 25-37, 2001.

[38] N. Karoui-Yaakoub, D. Zaghbib-Turki, and G. Keller, "The Cretaceous-Tertiary (K-T) mass extinction in planktic foraminifera at Elles I and El Melah, Tunisia," Palaeogeography, Palaeoclimatology, Palaeoecology, vol. 178, no. 3-4, pp. 233-255, 2002.

[39] G. Keller, T. Adatte, W. Stinnesbeck, V. Luciani, N. KarouiYaakoub, and D. Zaghbib-Turki, "Paleoecology of the Cretaceous-Tertiary mass extinction in planktonic foraminifera," Palaeogeography, Palaeoclimatology, Palaeoecology, vol. 178, no. 3-4, pp. 257-297, 2002.

[40] E. Robin and R. Rocchia, "Ni-rich spinel at the CretaceousTertiary boundary of El Kef, Tunisia," Bulletin de la Société Géologique de France, vol. 169, pp. 365-372, 1998.

[41] J. Smit, "Discovery of a planktonic foraminiferal association between the Abathomphalus mayaroensis Zone and the "Globigerina” eugubina Zone at the Cretaceous/Tertiary boundary 
in the Barranco del Gredero (Caravaca, SE Spain). A preliminary report," Proceedings of the Koninklijke Nederlandse Akademie van Wetenschappen, vol. 80, no. 4, pp. 280-301, 1977.

[42] J. Smit, "The Cretaceous/Tertiary transition in the Barranco del Gredero," in Proceedings of the 2nd C-T Boundary Events Symposium, W. K. Christensen and T. Birkelund, Eds., pp. 156163, Spain, 1979.

[43] J. Smit and J. Hertogen, "An extraterrestrial event at the Cretaceous-Tertiary boundary," Nature, vol. 285, no. 5762, pp. 198-200, 1980.

[44] L. W. Alvarez, W. Alvarez, F. Asaro, and H. V. Michel, "Extraterrestrial cause for the Cretaceous-Tertiary extinction," Science, vol. 208, no. 4448, pp. 1095-1108, 1980.

[45] J. Smit and G. Klaver, "Sanidine spherules at the CretaceousTertiary boundary indicate a large impact event," Nature, vol. 292, no. 5818, pp. 47-49, 1981.

[46] J. Smit and W. G. H. Z. ten Kate, "Trace-element patterns at the Cretaceous-Tertiary boundary-Consequences of a large impact," Cretaceous Research, vol. 3, no. 3, pp. 307-332, 1982.

[47] A. Montanari, R. L. Hay, W. Alvarez et al., "Spheroids at the Cretaceous-Tertiary boundary are altered impact droplets of basaltic composition," Geology, vol. 11, no. 11, pp. 668-671, 1983.

[48] D. J. DePaolo, F. T. Kyte, B. D. Marshall, J. R. O’Neil, and J. Smit, "Rb-Sr, Sm-Nd, K-Ca, O, and H isotopic study of CretaceousTertiary boundary sediments, Caravaca, Spain: evidence for an oceanic impact site," Earth and Planetary Science Letters, vol. 64, no. 3, pp. 356-373, 1983.

[49] M. R. Rampino and R. C. Reynolds, "Clay mineralogy of the Cretaceous-Tertiary boundary clay," Science, vol. 219, no. 4584, pp. 495-498, 1983.

[50] F. T. Kyte, J. Smit, and J. T. Wasson, "Siderophile interelement variations in the Cretaceous-Tertiary boundary sediments from Caravaca, Spain," Earth and Planetary Science Letters, vol. 73, no. 2-4, pp. 183-195, 1985.

[51] S. Vannuci, M. G. Pancani, O. Vaselli, and N. Caradosi, "Mineralogical and geochemical features of the Cretaceous-Tertiary boundary in the Barranco del Gredero section (Caravaca, SE Spain)," Chemical Erde, vol. 50, pp. 189-202, 1990.

[52] E. Robin, D. Boclet, P. Bonté, L. Froget, C. Jéhanno, and R. Rocchia, "The stratigraphic distribution of Ni-rich spinels in Cretaceous-Tertiary boundary rocks at El Kef (Tunisia), Caravaca (Spain) and Hole 761C (Leg 122)," Earth and Planetary Science Letters, vol. 107, no. 3-4, pp. 715-721, 1991.

[53] B. Schmitz, "Geochemical high-resolution stratigraphy of Cretaceous/Tertiary boundary in Denmark, Spain and New Zealand," in Extinction and the Fossil Record, E. Molina, Ed., vol. 5, pp. 121-140, SIUZ Cuadernos Interdisciplinares, 1994.

[54] M. Ortega Huertas, F. Martínez Ruíz, I. Palomo, and H. Chamley, "Comparative mineralogical and geochemical clay sedimentation in the Betic Cordilleras and Basque-Cantabrian Basin areas at the Cretaceous-Tertiary boundary," Sedimentary Geology, vol. 94, no. 3-4, pp. 209-227, 1995.

[55] F. Martínez Ruíz, M. Ortega Huertas, I. Palomo, and P. Acquafredda, "Quench textures in altered spherules from the Cretaceous-Tertiary boundary layer at Agost and Caravaca, SE Spain," Sedimentary Geology, vol. 113, no. 1-2, pp. 137-147, 1997.

[56] A. Shukolyukov and G. W. Lugmair, "Isotopic evidence for the cretaceous-tertiary impactor and its type," Science, vol. 282, no. 5390, pp. 927-929, 1998.

[57] T. Arinobu, R. Ishiwatari, K. Kaiho, and M. A. Lamolda, "Spike of pyrosynthetic polycyclic aromatic hydrocarbons associated with an abrupt decrease in $\delta 13 \mathrm{C}$ of a terrestrial biomarker at the Cretaceous-Tertiary boundary at Caravaca, Spain," Geology, vol. 27, no. 8, pp. 723-726, 1999.

[58] K. Kaiho and M. A. Lamolda, "Catastrophic extinction of planktonic foraminifera at the cretaceous-tertiary boundary evidenced by stable isotopes and foraminiferal abundance at Caravaca, Spain," Geology, vol. 27, no. 4, pp. 355-358, 1999.

[59] R. Coccioni, L. Fabbrucci, and S. Galeotti, “Terminal Cretaceous deep-water benthic foraminiferal decimation survivorship and recovery at Caravaca (SE Spain)," Paleopelagos, vol. 3, pp. 3-24, 1993.

[60] R. Coccioni and S. Galeotti, "K-T boundary extinction: geologically instantaneous or gradual event? Evidence from deep-sea benthic foraminifera," Geology, vol. 22, no. 9, pp. 779-782, 1994.

[61] L. Alegret, "Recovery of the deep-sea floor after the CretaceousPaleogene boundary event: the benthic foraminiferal record in the Basque-Cantabrian basin and in South-eastern Spain," Palaeogeography, Palaeoclimatology, Palaeoecology, vol. 255, no. 1-2, pp. 181-194, 2007.

[62] F. J. Rodríguez-Tovar and A. Uchman, "Ichnological analysis of the Cretaceous-Palaeogene boundary interval at the Caravaca section, SE Spain," Palaeogeography, Palaeoclimatology, Palaeoecology, vol. 242, no. 3-4, pp. 313-325, 2006.

[63] J. Leclerc, "Etude géologique du massif du maigmó et de ses abords," Tesis De 3er Ciclo De Géologie Structurales, pp. 96-100, 1971.

[64] A. von Hillebrandt, "Bioestratigrafía del paleógeno del sureste de españa (Provincias de Murcia y Alicante)," Cuadernos Geológicos, vol. 5, pp. 135-153, 1974.

[65] J. J. Groot, R. B. G. de Jonge, C. G. Langereis, W. G. H. Z. ten Kate, and J. Smit, "Magnetostratigraphy of the CretaceousTertiary boundary at Agost (Spain)," Earth and Planetary Science Letters, vol. 94, no. 3-4, pp. 385-397, 1989.

[66] J. Smit, "Meteorite impact, extinctions and the CretaceousTertiary Boundary," Geologie en Mijnbouw, vol. 69, no. 2, pp. 187-204, 1990.

[67] A. Pardo, N. Ortiz, and G. Keller, "Latest Maastrichtian and Cretaceous-Tertiary Boundary Foraminiferal Turnover and Environmental Changes at Agost, Spain," in Cretaceous Tertiary Mass Extinctions. Biotic and Environmental Changes, N. MacLeod and G. Keller, Eds., pp. 139-171, W.W. Norton \& Company, 1996.

[68] E. Molina, I. Arenillas, and J. A. Arz, "Mass extinction in planktic foraminifera at the Cretaceous/Tertiary boundary in subtropical and temperate latitudes," Bulletin de la Société Géologique de France, vol. 169, no. 3, pp. 351-363, 1998.

[69] L. Alegret, E. Molina, and E. Thomas, "Benthic foraminiferal turnover across the Cretaceous/Paleogene boundary at Agost (southeastern Spain): paleoenvironmental inferences," Marine Micropaleontology, vol. 48, no. 3-4, pp. 251-279, 2003.

[70] G. W. van Veen, Geological investigations in the region west of Caravaca, South-Eastern Spain [Tesis], Universidad de Amsterdam, 1969.

[71] J. A. Vera, "La Cordillera Bética. Las Zonas Externas de las Cordilleras Béticas," in Geología de España, vol. 2, pp. 218-251, Libro Jubilar J. M. Ríos, 1983.

[72] C. Seyve, "Nannofossil biostratigraphy of the CretaceousTertiary boundary in the French Basque country," Bulletin Centres de Recherche Exploration-Production Elf-Aquitaine, vol. 14, no. 2, pp. 553-572, 1990. 
[73] S. K. Haslett, "Planktonic foraminiferal biostratigraphy and palaeoceanography of the Cretaceous-Tertiary boundary section at Bidart, south-west France," Cretaceous Research, vol. 15, no. 2, pp. 179-192, 1994.

[74] E. Martini, "Standard Tertiary and Quaternary calcareous nannoplankton zonation," in Proceedings of the 2nd Planktonic Conference, A. Farinacci, Ed., vol. 2, pp. 739-785, Rome, Italy, 1970.

[75] A. J. T. Romein and J. Smit, "The Cretaceous/Tertiary boundary: calcareous nannofossil and stable isotopes," Proceedings Koninklijke Nederlandse Akademie van Wetenschappen, vol. 84, pp. 295-314, 1981.

[76] M. Renard, O. Delacotte, and R. Letolle, "Le strontium et les isotopes stables dans les carbonates totaux de quelques sites de l'atlantique et de la Téthys," Bulletin de la Société Géologique de France, vol. 24, pp. 519-534, 1982.

[77] B. K. Nelson, G. K. MacLeod, and P. D. Ward, "Rapid change in strontium isotopic composition of sea water before the Cretaceous/Tertiary boundary," Nature, vol. 351, no. 6328, pp. 644-647, 1991.

[78] P. Bonté, O. Delacotte, M. Renard et al., "An iridium rich layer at the Cretaceous/Tertiary boundary in the Bidart section (southern France)," Geophysical Research Letters, vol. 11, no. 5, pp. 473-476, 1984.

[79] O. Delacotte, M. Renard, C. Laj, K. Perch-Nielson, I. PremoliSilva, and S. Clauser, "Magnétostratigraphie et bio stratigraphie du passage Crétacé-Tertiaire de la coupe de Bidart (Pyrénées Atlantiques)," Bulletin du Bureau des Recherches Géologiques et Minières, vol. 3, pp. 243-254, 1985.

[80] F. Minoletti, M. de Rafelis, M. Renard, and S. Gardin, "Reworking of Maastrichtian-like calcareous nannofossils in the lowermost Danian sediments of bidart section (France): isotopic evidence (carbon and oxygen)," Revue de Micropaleontologie, vol. 47, no. 3, pp. 145-152, 2004.

[81] B. Peynernes, M. J. Fondecave-Wallez, Y. Gourinard, and P. Eichene, "Stratigraphie séquentielle comparée et grade-datation par les foraminifères planctoniques du Campano-Maastrichtien et du Paléocène de quelques sites d'Europe sud-occidentale et d'Afrique du Nord," Conte Rendu Académie des Sciences, vol. 324, pp. 839-846, 1997.

[82] B. Galbrun, "Normal polarity magnetic overprint of chron C29r by diagenetic hematite growth in red marly limestones from Bidart and Loya sections (Pays-Basque, France)," EUG 9, Strasbourg, Terra Nova 9, 1997.

[83] B. Galbrun and S. Gardin, "New chronostratigraphy of the Cretaceous-Paleogene boundary interval at Bidart (France)," Earth and Planetary Science Letters, vol. 224, no. 1-2, pp. 19-32, 2004.

[84] R. Rocchia, D. Boclet, P. Bonte, J. Devineau, C. Jehanno, and M. Renard, "Comparaison des distributions de l'iridium observées à la limite Crétacé-Tertiaire dans divers sites Européens," Mémoire de la Société Géologique de France, vol. 150, pp. 95-103, 1987.

[85] K. Perch-Nielsen, "Calcareous nannofossils at the Cretaceous/Tertiary boundary near Biarritz, France," in CretaceousTertiary Boundary Events, W. K. Christensen, Ed., vol. 2, pp. 151155, University of Copenhagen, Copenhagen, Denmark, 1979.

[86] A. Gorostidi and M. A. Lamolda, "La nanoflora calcárea y el tránsito KT de la sección de Bidart (SW de Francia)," Revista Española de Paleontoleontología, pp. 153-168, 1995.

[87] M. J. Fondecave-Wallez, B. Peybernes, and P. Eichene, "Mise en évidence micropaléontologique d’un flysch Ypréso-Lutétien, ex Crétacé, à matériel triasique resédimenté, dans la coupe de Bidart Nord (Pyrénées atlantiques, Sud-Ouest de la France)," Géologie de la France, vol. 3, pp. 47-56, 1995.

[88] E. Apellaniz, J. I. Baceta, G. Bernaola-Bilbao et al., "Analysis of uppermost Cretaceous-lowermost Tertiary hemipelagic successions in the Basque Country (western Pyrenees): evidence for a sudden extinction of more than half planktic foraminifer species at the K/T boundary," Bulletin de la Societe Geologique de France, vol. 168, no. 6, pp. 783-793, 1997.

[89] P. D. Ward, "Maastrichtian ammonite and inoceramid ranges from Bay of Biscay Cretaceous-Tertiary boundary sections," in Palaeontology and Evolution; Extinction, M. A. Lamolda, E. G. Kauffman, and O. H. Walliser, Eds., Revista Española de Paleontología, pp. 119-126, 1988.

[90] P. D. Ward and W. J. Kennedy, "Maastrichtian ammonites from the Biscay region (France Spain)," Paleontological Society Memoir, vol. 34, pp. 1-58, 1993.

[91] E. A. Pessagno, "Upper Cretaceous planktonic Foraminifera from the Western Gulf Coastal Plain," Paleontogr, vol. 537, pp. 243-444, 1967.

[92] J. A. Postuma, Manuel of Planktonic Foraminifera, Elsevier, Amsterdam, The Netherlands, 1971.

[93] I. Premoli Silva and H. M. Bolli, "Late cretaceous to eocene planktonic foraminifera and stratigraphy of leg 15 sites in the Caribbean Sea," in Initial Reports of the Deep Sea Drilling Project 15, N. T. Edgar and J. B. Saunders, Eds., pp. 499-547, Government Printing Office, Washington, DC, USA, 1973.

[94] J. Sigal, "Essai de zonation du Crétacé méditerranéen à l’aide des foraminifères planctoniques," Geologie Mediterraneenne, vol. 4, no. 2, pp. 99-108, 1977.

[95] F. Robaszynski, M. Caron, J. M. Gonzalez Donoso, and A. A. $\mathrm{H}$. Wonders, "Atlas of late cretaceous globtruncanids," Revue de Micropaléontologie, vol. 26, p. 305, 1984.

[96] M. Caron, "Cretaceous planktonic foraminifera," in Plankton Stratigraphy, H. Bolli, J. B. Saunders, and K. Perch Neilson, Eds., pp. 17-86, University Press, Cambridge, UK, 1985.

[97] B. T. Huber, "Paleocene and early neogene planktonic foraminifer biostratigraphy of sites 738 and744, Kerguelen Plateau (Southern Indian Ocean)," in Proceedings of the Ocean Drilling Program, Scientific Results, J. Barron and B. Larsen, Eds., vol. 119, pp. 427-449, Ocean Drilling Program, College Station, Tex, USA, 1991.

[98] J. A. Arz and I. Arenillas, "Extinción en masa catastrófica de foraminíferos planctónicos en el límite Cretácico/Terciario del Pirineo occidental (España)," Revista de la Sociedad Mexicana de Paleontología, vol. 8, no. 2, pp. 146-162, 1998.

[99] G. Keller, "The Cretaceous-Tertiary boundary transition in the Antarctic Ocean and its global implications," Marine Micropaleontology, vol. 21, no. 1-3, pp. 1-45, 1993.

[100] I. Arenillas, J. A. Arz, E. Molina, and C. Dupuis, "The Cretaceous/Paleogene (K/P) boundary at Aïn Settara, Tunisia: sudden catastrophic mass extinction in planktic foraminifera," Journal of Foraminiferal Research, vol. 30, no. 3, pp. 202-218, 2000.

[101] U. Rohl, J. G. Ogg, T. L. Geib, and G. Wefer, "Astronomical calibration of the Danian time scale," in Western North Atlantic Palaeogene and Cretaceous Palaeoceanography, D. Kroon, R. D. Norris, and A. Klaus, Eds., vol. 183 of Geological Society Special Publication, pp. 163-183, 2001.

[102] V. P. Leonov and G. P. Alimarina, "Stratigraphy and planktonic foraminifera of the Cretaceous-Paleogene "Transition" Beds 
of the central part of the North Caucasus: Collected Papers Geological Faculty, University of Moscow," in Proceedings of the 21st International Geological Congress, pp. 29-60, 1961.

[103] J. A. Arz and E. Molina, "Bioestratigrafía y cronoestratigrafía con foraminíferos planctónicos del Campaniense superior y Maastrichtiense de latitudes subtropicales y templadas (España, Francia y Tunicia)," Neues Jahrbuch Für Geologie Und Paläontologie Abhandlungen, vol. 224, no. 2, pp. 161-195, 2002.

[104] W. A. Berggren and P. N. Pearson, "A revised tropical to subtropical Paleogene planktonic foraminiferal zonation," The Journal of Foraminiferal Research, vol. 35, no. 4, pp. 279-298, 2005.

[105] J. Smit, W. Alvarez, A. Montanari et al., ““'Tektites” and microkrystites at the Cretaceous/Tertiary boundary: two strewn fields, one crater?" Proceedings of Lunar and Planetary Science, vol. 22, pp. 87-100, 1992. 

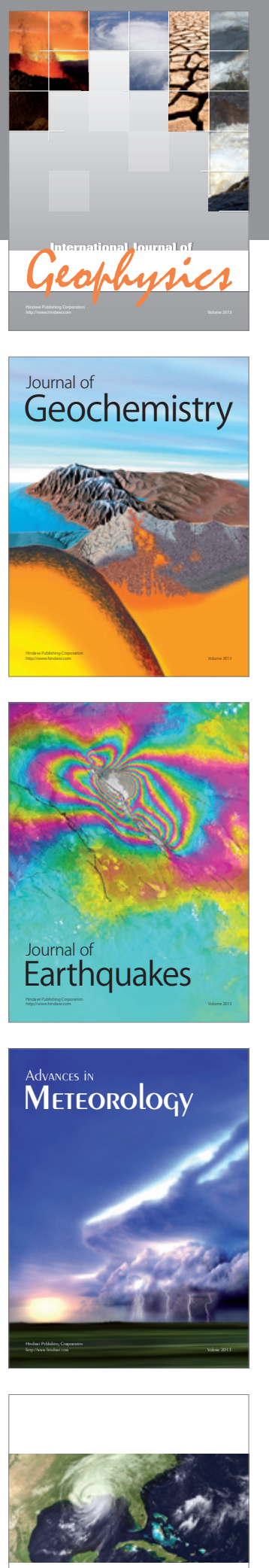

ISRN

Meteorology
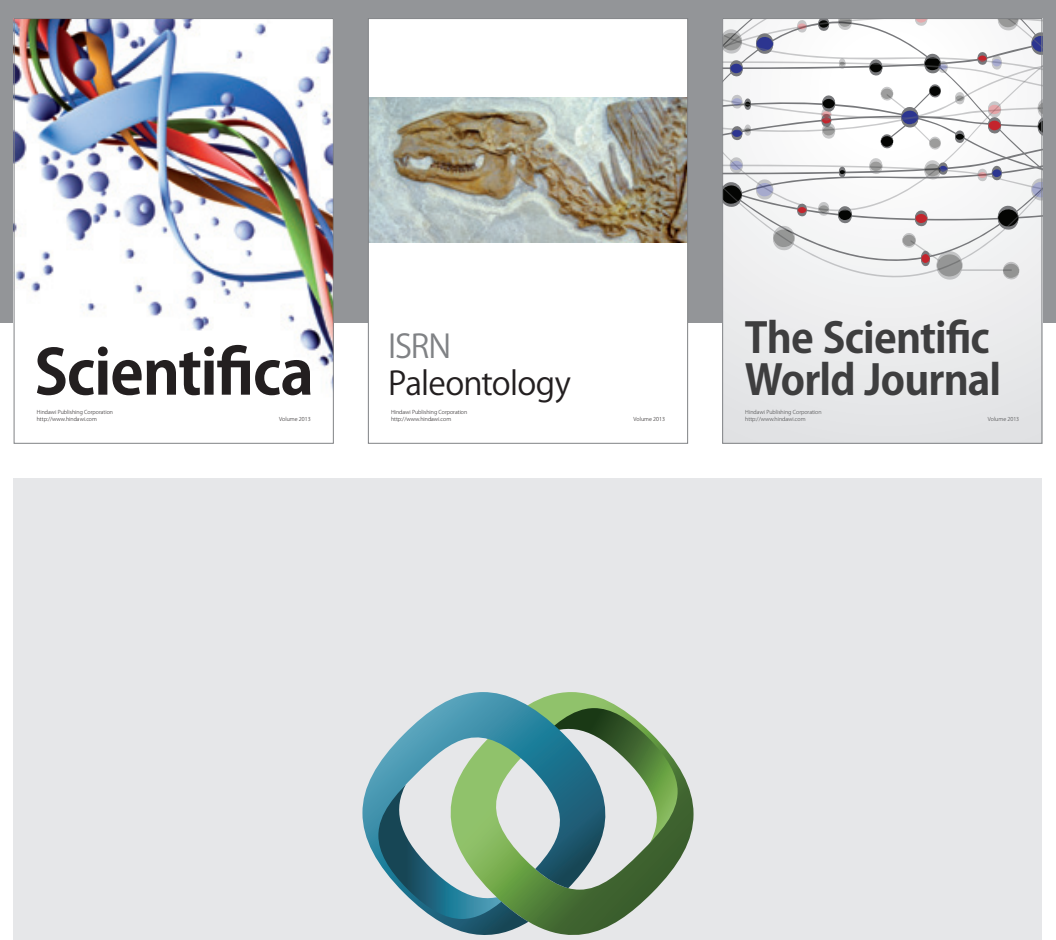

\section{Hindawi}

Submit your manuscripts at

http://www.hindawi.com
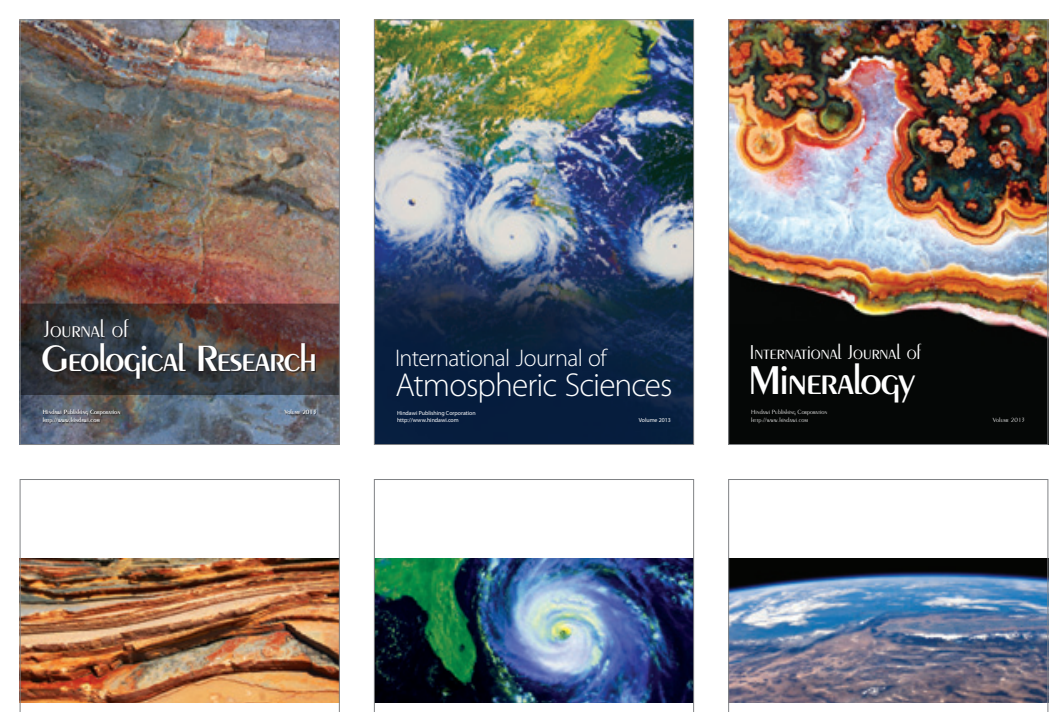

ISRN

Atmospheric

Sciences

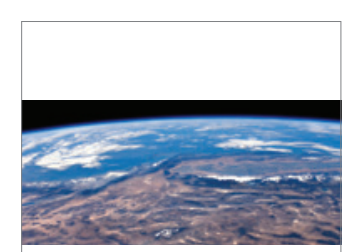

ISRN

Geophysics
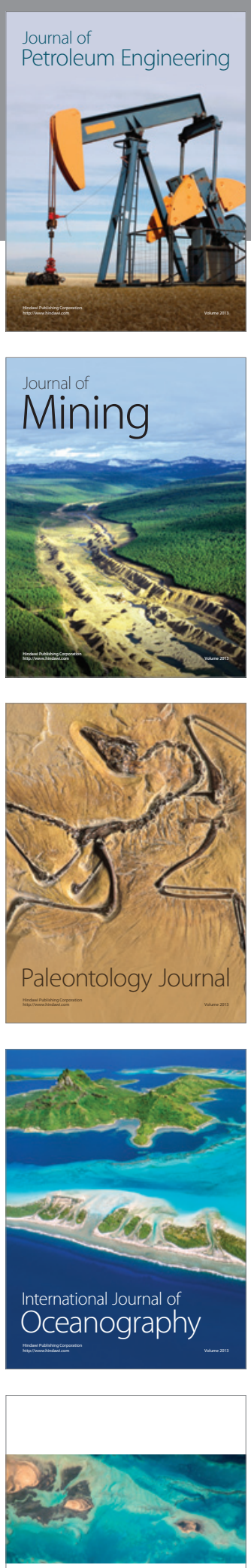

ISRN

Oceanography 